WIDER Working Paper 2014/106

\title{
An integrated analysis of economywide effects of climate change
}

Hasan Dudu and Erol H. Çakmak

August 2014 
Abstract: The effects of climate change in Turkey are expected to be significant. The aim of this paper is to quantify the effects of climate change on the overall economy by using an integrated framework incorporating a computable general equilibrium model and a crop water requirement model for the period 2010-99. The results suggest that the economic effects of climate change will not be significant until the late 2030s; therefore Turkey has a chance to develop appropriate adaptation policies. After the 2030s, the effects of climate change are likely to be significant, with agriculture and food production being the most affected sectors.

Keywords: agriculture, climate change, computable general equilibrium, integrated assessment, Turkey

JEL classification: C68, Q10, Q54

Acknowledgements: This paper has benefited from the comments and suggestions of various researchers who participated in the UNU-WIDER Conference on 'Climate Change and Development Policy' held in Helsinki, Finland, 28-29 September 2012. We would like to thank Wally Tyner and James Thurlow for their valuable comments. The usual disclaimer applies.

${ }^{1}$ European Commission Joint Research Center Institute for Prospective Technological Studies, Seville, and METU Department of Economics, Ankara; 2TED University Department of Economics, Ankara; corresponding author: hasan@dudu.gen.tr

This study has been prepared within the UNU-WIDER project on 'The Middle East, North Africa, and Climate Change', directed by Imed Drine and Wallace E. Tyner.

Copyright (C) UNU-WIDER 2014

ISSN 1798-7237 ISBN 978-92-9230-827-8

Typescript prepared by Judy Hartley for UNU-WIDER.

UNU-WIDER gratefully acknowledges the financial contributions to the research programme from the governments of Denmark, Finland, Sweden, and the United Kingdom.

The World Institute for Development Economics Research (WIDER) was established by the United Nations University (UNU) as its first research and training centre and started work in Helsinki, Finland in 1985. The Institute undertakes applied research and policy analysis on structural changes affecting the developing and transitional economies, provides a forum for the advocacy of policies leading to robust, equitable and environmentally sustainable growth, and promotes capacity strengthening and training in the field of economic and social policy-making. Work is carried out by staff researchers and visiting scholars in Helsinki and through networks of collaborating scholars and institutions around the world.

UNU-WIDER, Katajanokanlaituri 6 B, 00160 Helsinki, Finland, wider.unu.edu

The views expressed in this publication are those of the author(s). Publication does not imply endorsement by the Institute or the United Nations University, nor by the programme/project sponsors, of any of the views expressed. 
The effects of climate change in Turkey, which is already a water stressed country, are expected to be significant. The aim of this study is to quantify the effects of climate change on the overall economy. We use an integrated framework that incorporates the results of a crop water requirement model in a computable general equilibrium (CGE) model for the period 2010-99. Since agriculture is the most important sector that will be affected by climate change, analysis of climate change effects on the overall economy necessitates taking into account backward and forward linkages to agriculture. The CGE model establishes the links between agriculture, the other sectors, and also with the economic agents in 12 NUTS-1 regions. ${ }^{1}$ A crop water requirement model is used to translate the results of global climate models to the changes in yields and irrigation requirements for the period 2008-99 at 81 NUTS-3 regions for 35 crops. The results of the crop water requirement model are then introduced into the CGE model as climate shocks.

The results suggest that the economic effects of climate change will not be significant until the late 2030s; which allows Turkey to develop appropriate adaptation policies. However, after the 2030s, the effects of climate change will be significant. Production patterns and relative prices will change drastically. The economic effects differ among regions. The effects are milder in the regions where irrigated agriculture is relatively low. This suggests that climate change policy needs to be region-specific. Agriculture and food production are the most affected sectors. Increasing irrigation requirements will cause farmers to reduce irrigated production. Combined with the decline in yields, this will lead to the deterioration of agricultural production and an increase in agricultural prices. Consequently the loss in household welfare will be significant. Part of the decline in production can be compensated for by imports, causing an increase in agrofood trade. The trade balance will worsen with declining manufacturing exports due to increasing production costs.

In the following sections we will first give a survey of studies related to the effects of climate change on agriculture and the overall economy in Turkey. Then we will present the modelling approach and the models that are used in this study. Afterwards, we will describe the data used in the models. Results and discussions will follow. We reserved the last section for concluding remarks.

\section{Climate change and the agricultural sector in Turkey}

A significant effort has been made by scientists from various disciplines to shed light on the causes and effects of climate change in recent years (Tol 2010). Although there are still some controversies about the details (Idso and Singer 2009), it is widely accepted that the effects of climate change have already started to be felt, and the significance of the impacts is expected to increase throughout the twenty-first century (Agrawala and Fankhauser 2008; Parry et al. 2007; Stern, 2006). Although, a wide range of social and physical effects has been linked to climate change, the most significant effects are expected to be increasing temperatures accompanied by declining precipitation, as well as increasing frequency of climatic extremes (Stern 2006). Hence, agricultural production, which ranks high in terms of climate dependence, is likely to be the most vulnerable sector (Fankhauser 2005). The changes in temperature and precipitation will affect the

\footnotetext{
${ }^{1}$ Nomenclature of Territorial Units for Statisistics - Level 1. Details of this classification are given in TurkStat (2014).
} 
yields in crop production, while climate-related risks will increase due to the increasing frequency of climatic extremes (Rosegrant et al. 2008).

The effects of climate change have already started to be observed in Turkey in the form of changes in mean temperatures, precipitation (Durdu 2010; Kadıŏlu 2008), growing degree days (Kadıŏlu et al. 2001), number of frost days (Şensoy et al. 2008) and frequency of climatic extremes (Şensoy et al. 2008). The effect of climate change on agricultural production in Turkey is expected to be significant since agricultural production is heavily dependent on climatic conditions. A significant part of the agricultural production is held on rainfed land, making the production significantly sensitive to changes in precipitation (Kadığlu 2008). Research and development of new drought-resistant crop varieties are also quite limited. Further, although the share of agricultural value added in GDP has declined to 10 per cent in recent years (TurkStat 2010a), its share in employment is still significant, at 25 per cent (TurkStat 2010b). As such, agriculture remains the most important source of income for the rural population.

The number of studies investigating the economic effects of climate change in Turkey has started to increase in recent years. These studies can be grouped in five categories. The first group consists of papers that survey the global literature and attempt to draw conclusions about the Turkish economy by analysing the results of existing global models (Arslan-Alaton et al. 2011; Aydinalp et al. 2008; Kaygusuz 2004; Önder and Önder 2007). The work in the second group focuses on greenhouse gas (GHG) abatement policies (Kumbaroğlu et al. 2008; Telli et al. 2008; Tunç et al. 2007) and attempt to model the link between climate change and economy by evaluating the effects of different policy options. The third group of studies uses general circulation, hydrological, regional climate- or crop-based models to estimate the probable effects on non-economic indicators such as the availability of water or growing degree days without any reference to their implications for agricultural production or economy (Durdu 2010; Fujihara et al. 2008; Göncü 2005; Kadığlu and Saylan 2001; Komuscu et al. 1998; Onol et al. 2009; Şensoy et al. 2008). In the fourth group, there are a few studies that link the changes in climate variables under different climate change scenarios to agricultural production (Cline 2007; Kapur et al. 2007; Özdoğan 2011). Lastly, Dellal and Mccarl (2009) investigate the impact of climate change using a sector model with restricted coverage of agriculture, and Dudu et al. (2010) try to link climate change projections with the overall economy.

Cline (2007) presents a detailed impact analysis of climate change in 60 countries, including Turkey, by downscaling the results of five global circulation models (GCMs) Cline (2007) reports that the increase in average temperature will be between $1.1{ }^{\circ} \mathrm{C}$ and $1.6{ }^{\circ} \mathrm{C}$, while average precipitation will decline by 30 per cent, which translates to an 11.8 per cent decline in average agricultural yield for the period 2070-99. This will result in a 16 per cent loss in the value added produced by the agricultural sector (Cline 2007). Cline (2007) also reveals that the initial $1-2{ }^{\circ} \mathrm{C}$ increase in temperature will in fact benefit the agricultural sector. However, the effects will be reversed when the increase in temperature is higher than $2{ }^{\circ} \mathrm{C}$ (Cline 2007). The results indicate that estimates of climate change effects for Turkey have the highest coefficient of variation across different global climate models and are probably less robust to different model assumptions.

Kapur et al. (2007) attempt to link the climate change effects in Turkey to agricultural production. They employ a regional climate model to estimate the effects of climate change on wheat production for the period 2070-99 under A2 scenario of the IPCC (Intergovernmental Panel on Climate Change) in the Çukurova Basin, which is one of Turkey's most advanced regions in agricultural production. Their results suggest a 35 per cent decline in precipitation 
accompanied by a $2.8{ }^{\circ} \mathrm{C}$ increase in the mean temperature. However, they do not report any quantitative results for the probable change in wheat yield.

Recently, Özdoğan (2011) reported the results of a crop model. The impact of climate change is obtained from a GCM. The study analyses the effects on wheat production in the Thrace region. Özdoğan (2011) reports that $\mathrm{CO}_{2}$ effects are likely to be small and that there will be a 15-20 per cent decline in the wheat yield.

Although these studies report the impact of climate change on yields or water availability, they still do not give much information about the economic effects on the agricultural sector. Furthermore, these studies also lack spatial and sectoral depth, in the sense that they merely focus on either the national level or on analysing specific sub-regions and they generally limit their analysis to a few major crops.

There are only two well-documented studies in the literature that employ economic models to investigate the implications of climate projections under different climate change scenarios. Dellal and Mccarl (2009) use a partial equilibrium model for the agricultural sector to investigate the effects of a climate change on production. Dudu et al. (2010), on the other hand, use a CGE model to analyse the effects of yield changes on the overall economy. Both models suffer from various deficiencies. In Dellal and Mccarl (2009) the average of results from a global climate model is used to estimate yield responses. The regional dimension of the model used is outdated and is not compatible with the NUTS classifications of TurkStat. Furthermore, the study runs simulations for a limited number of crops. Dudu et al. (2010) use the average of expected yield changes compiled from existing literature. The regions chosen are aggregated and they use a 2003 social accounting matrix.

Consequently, there is a need for a more detailed economic analysis of climate change by combining the results of climate models with economic models at the regional level. In this study, we aim to improve the current modelling efforts in the literature by using an integrated approach to evaluate the effects of climate change on the overall Turkish economy in a detailed regional setting. For this purpose, we use a crop water requirement model to translate the regionalized results of a global climate model to yield shocks and irrigation requirement changes. These changes are introduced as productivity shocks to a CGE model. The following section presents the modelling approach for the CGE model in detail and the crop water requirement model. We then present the data and aggregated results of the crop water model, followed by the results of the CGE analysis. The last section is reserved for the concluding remarks.

\section{$3 \quad$ Integrated modelling approach}

Climate change is a complex issue and any complete assessment of its effects needs to take into account the interactions of physical, economic and social factors. Consequently, a comprehensive impact assessment requires different types of models. Complicated climate and hydrology models are needed to estimate the physical effects at the global level. The estimates from these models then need to be downscaled to smaller spatial resolutions to obtain the effects at the regional level. In addition, the interaction within an economy and the rest of the world needs to be considered in detail to have a solid interpretation of the economic effects. As mentioned before, climate change is expected to affect the economy via the agricultural sector. Hence, a special impact assessment model is required to link the results of climate models to the economic models. Therefore, complete impact analysis of climate change necessitates the integration of physical models, specific impact assessment models and economic models. 
This 'three pillar' approach has started to dominate the literature recently, supported by the availability of disaggregated climate change data and by increasing computational power. GCMs are now used extensively to make projections related to the main climatic variables under different scenarios. Although the results of these models are controversial, especially at the regional level, the mean values of the results from many available GCMs are used as a proxy. The type and specification of special impact models used to translate GCM outputs to economic impacts differ according to the aim of the study. Lastly, CGE modelling has become the standard approach to estimating economic effects.

There is a vast literature related to the agricultural and economywide effects of climate change. The literature survey here will selectively consider the studies that adopted similar approaches to the one adopted in this study. More comprehensive surveys on the integrated approach can be found in Hertel and Rosch (2010) and also in Palatnik and Roson (2009).

In their study Bosello and Zhang (2005) use a GCM that combines a crop-growth model with a global CGE model (GTAP-E). The climate scenario is endogenously produced by the economic model. The results indicate that climate change has a limited impact on agricultural sectors mainly due to the smoothing effect of economic adaptation. Bosello and Zhang (2005) are separated from the other studies since they report insignificant effects on agriculture.

Rosegrant et al. (2008) and Nelson et al. (2009) use a global food supply and demand model (IMPACT) together with a biophysical model (DSSAT) to estimate the impacts of climate change on agriculture at the global level. They report that climate change will affect human wellbeing negatively due to declining yields and increasing prices. Calorie availability will be worsened and child malnutrition will increase by 20 per cent. They estimate that US $\$ 1.7$ billion in 2000 prices is needed to offset the effect of climate change on calorie availability.

Cretegny (2009) develops a conceptual framework that uses an integrated approach at national and global levels. The study presents an implementation of bottom-up and top-down approaches for integrated modelling of climate change. In the bottom-up methodology, the projected changes in climatic variables obtained from multiple GCMs are first downscaled to local levels, and then they are used to estimate the vector of impacts on key economic sectors using sectorspecific impact assessment models. In the top-down methodology, the climate projections are used to derive regional sector-specific damage functions that are used to calibrate a global dynamic multi-sectoral CGE model.

Thurlow et al. (2012) investigate the effect of climate variability and climate change on the Zambian economy by using a hydro-crop model (CropWAT model of the Food and Agriculture Organization, FAO) for maize in Zambia together with a dynamic CGE model. They use historical climatic data and HadCM3 results from a hydro-crop model to obtain yield responses of maize under different drought and climate change scenarios. They estimate yield losses up to 50 per cent in years with severe drought. The results of the CGE model suggest that climate variability may result in US $\$ 4.3$ billion losses over a ten-year period, leaving 300,000 people below the poverty line. Climate change effects add another US $\$ 2.15$ billion to the losses; pushing 74,000 more people below the poverty line.

Ciscar et al. (2009) use various impact assessment models with a CGE (GEM-E3) model. Most EU countries are modelled individually in the CGE model. DSSAT crop models have been used to quantify the physical impact on agriculture. Their findings suggest that most European regions would experience yield improvements during the 2020s, but in the 2080s average crop yield will fall by 10 per cent. Southern Europe would experience relatively higher yield losses. They 
estimate that the annual damage of climate change to the EU economy in terms of GDP loss will be between $€ 20-65$ billion, implying 0.2 per cent and 1 per cent welfare losses, respectively.

Pauw et al. (2010) use a general equilibrium model (GEM) to estimate the economywide impact of production losses due to hydrological extremes in Malawi. Climate simulations are based on production loss estimates from stochastic drought and flood models. Results show that 1.7 per cent of GDP will be lost due to climate change, small farmers will be prominently affected, and food shortages are likely to affect urban households significantly.

Calzadilla et al. (2011) investigate the impact of variation in water availability due to climate change on global agricultural production. They use a multi-sectoral global CGE model (GTAPW) and a Global Environmental Model, which includes a dynamic river routing model (HadGEM1-TRIP), to simulate changes in temperature, precipitation and river flow over the next century under the IPCC scenarios. They report that global food production, welfare and GDP will decline. Food prices are expected to increase. They also show that countries are not only influenced by regional climate change, but also by climate-induced changes in competitiveness in global markets.

Fernandes et al. (2012) use an agro-ecological model together with an applied GEM (ENVISAGE) to assess the impact of climate change in Latin America. The agro-ecological model consists of crop development, soil types, water availability, abiotic factors, management and crop suitability components. The results suggest that there will be significant decline in the yields of major crops and the effects will be higher after 2050. Adaptation is partially effective in off-setting the climate change effects. Economic impacts are also significant, adding up to a 1.3 per cent decline in the region's GDP.

All studies share two common findings. The first is that climate change effects on the overall economy and particularly on agricultural production may be significant, especially for developing countries where the share of agricultural value added in GDP is high. Second, the effects accelerate in the second half of the twenty-first century, especially for developed countries. The results are region- and crop-specific, and aggregation at any level underestimates the effects. Adaptation policies can be effective to lessen the economic losses.

The modelling approach used in this study follows the three pillar approach presented in Figure 1. We use the output of a GCM as an input for the crop water requirement model to estimate the yield and irrigation water requirements of different crops. Then the output of the crop water requirement model is used as an input for the CGE model in the form of productivity shocks. Details of the modelling structure are provided in the next two sections. 
Figure 1: Summary of modelling approach

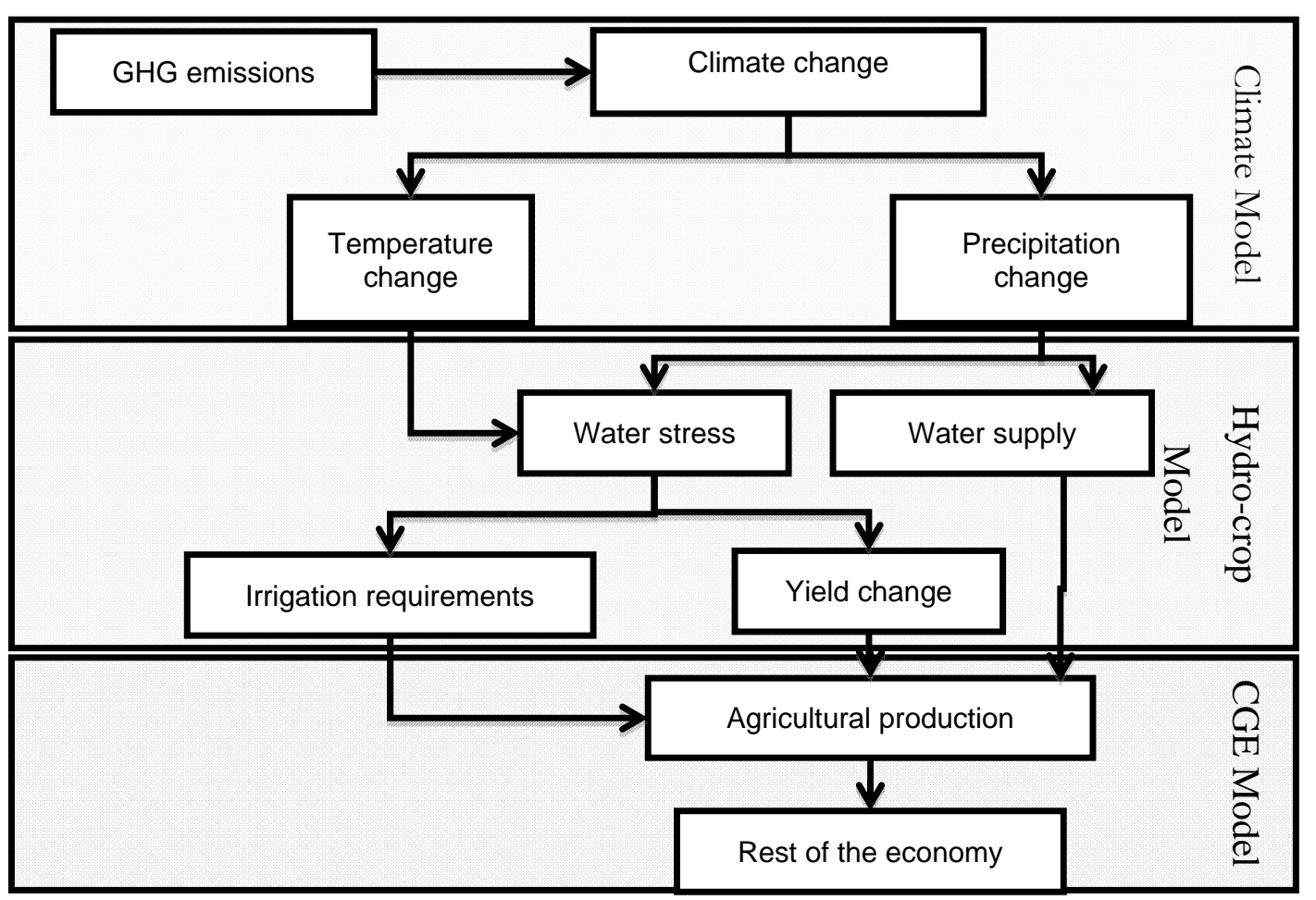

Source: Authors' illustration.

\subsection{Crop water requirement model}

The physical effects of climate change on agricultural commodity production are generally assessed by using hydrology and crop simulation models. These models take the forecasts of the major climatic variables - precipitation, temperature and wind speed-from the GCMs, and use them to calculate or estimate the induced yield changes. The aggregated results obtained from the crop water requirement model are presented in this section and the detailed description of the model can be found in Dudu (2013). The estimated changes in yields and irrigation requirements are then introduced into the CGE model as climate change shocks.

The average value of $E T_{0}$ (the reference evapotranspiration) is presented in Figure 2. $E T_{0}$ increases slowly until 2060. However, the oscillation around the mean value increases significantly between 2035 and 2060. Significant rise in the pace of increase in $E T_{0}$ is observed from 2060 to 2075, and the variation in $E T_{0}$ remains high after 2075. 


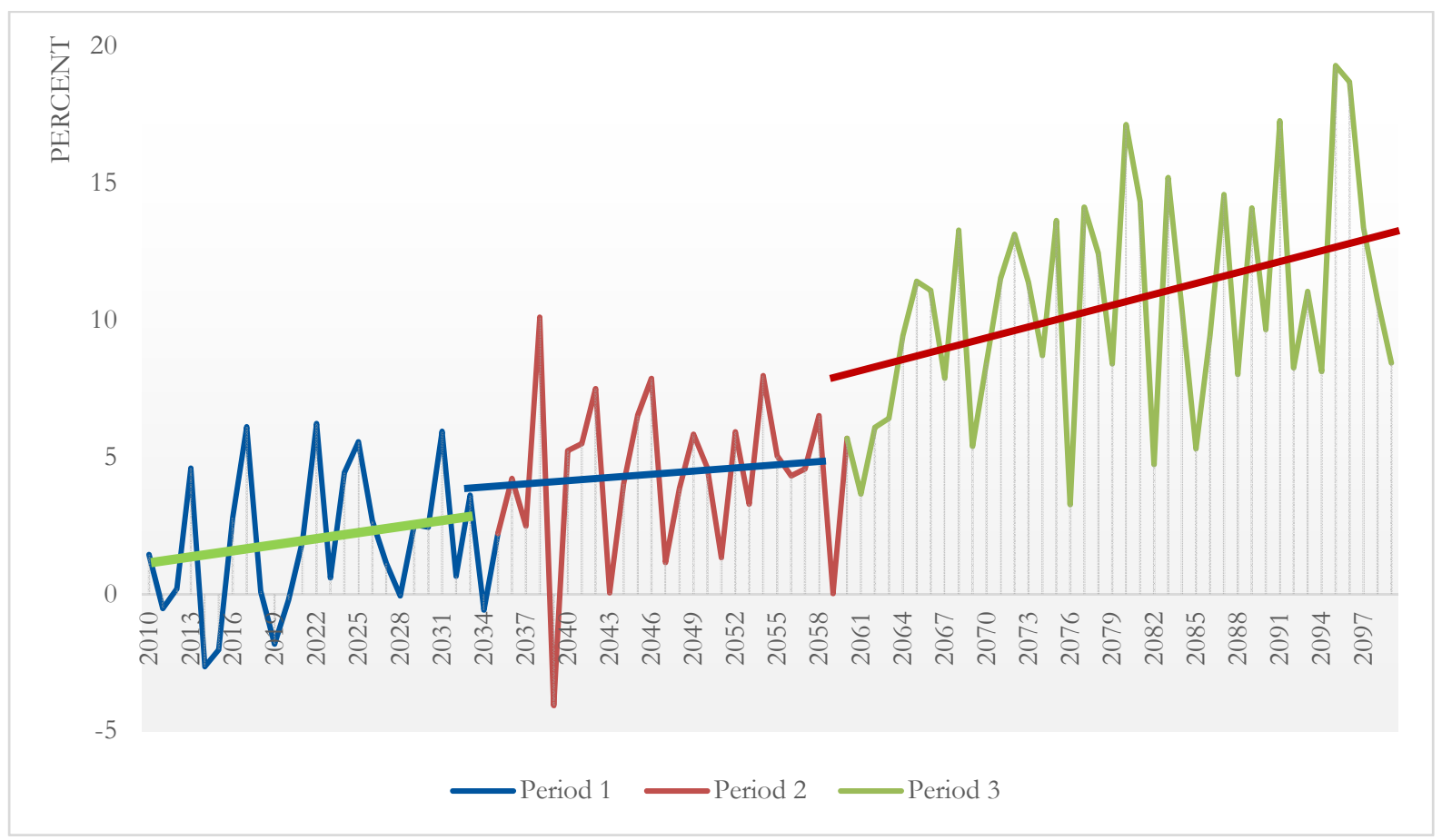

Source: Authors' calculations.

We use the change in yields for 35 crops (for details see Dudu 2013) to calculate the change in agricultural value added relative to the production value of agricultural products in 2008 for each NUTS-3 region. Then, we aggregate the results for NUTS-1 regions by using the following formula

$$
\Delta V A_{R 1}=\sum_{R 3 \in R 1} \frac{\sum_{c} \Delta Y_{c, R 3} \cdot P_{c, R 3} \cdot Q_{c, R 3}}{\sum_{c} P_{c, R 3} \cdot Q_{c, R 3}}
$$

where $\Delta Y_{c, R 3}$ is the change in yield, $P_{c, R 3}$ is the price, and $Q_{c, R 3}$ is the production quantity of crop $c$ in NUTS-3 region R3.

Monthly irrigation requirements for each crop in each region and year are calculated as the deficiency between precipitation and $E T_{s}$. The area of cultivated land in 2008 is used to find a weighted sum of the total irrigation for each NUTS-1 region, and also to determine a regionwide irrigation requirement per hectare.

$$
I R Q_{R 1, Y}=\frac{\sum_{R 3 \in R 1} \sum_{C} \sum_{M}\left(E T S_{C, R 3, M, Y}-P R_{R 3, M, Y}\right) A_{C, R 3,2008}}{\sum_{C} A_{C, R 3,2008}}
$$

where $E T S_{C, R 3, M, Y}$ is evapotranspiration of crop $C$ under water stress in region $\mathrm{R} 3$, month $M$ and year $Y . P R_{R 3, M, Y}$ is the effective precipitation in region $R 3$, month $M$ and year $Y . A_{C, R 3,2008}$ is the harvested area of crop $C$ in region $R 3$ in 2008. 
The change in the irrigation water requirement is calculated relative to the average irrigation water requirement for the period 2001-10.

$$
\Delta I R Q_{R 1, Y}=\frac{I R Q_{R 1, Y}}{\sum_{B=2001}^{2010} I R Q_{C, R 1, B} / 10}
$$

Figure 3 displays the estimated changes in yields and irrigation water requirements from 2001 to 2099. The changes in yields and water requirements follow slightly different trends than $E T_{0}$. Yield changes oscillate less in comparison with water requirements, which are highly dependent on precipitation. Both figures oscillate around base decade values until 2035. After 2035 the yields start to decline while irrigation requirements start to increase. Consequently, increase in irrigation requirements and decline in yields become significant after 2060. Lastly, note that variation in yields and irrigation requirements are significantly higher than the variation in $E T_{0}$.

Figure 3: Average yield change and irrigation water requirements

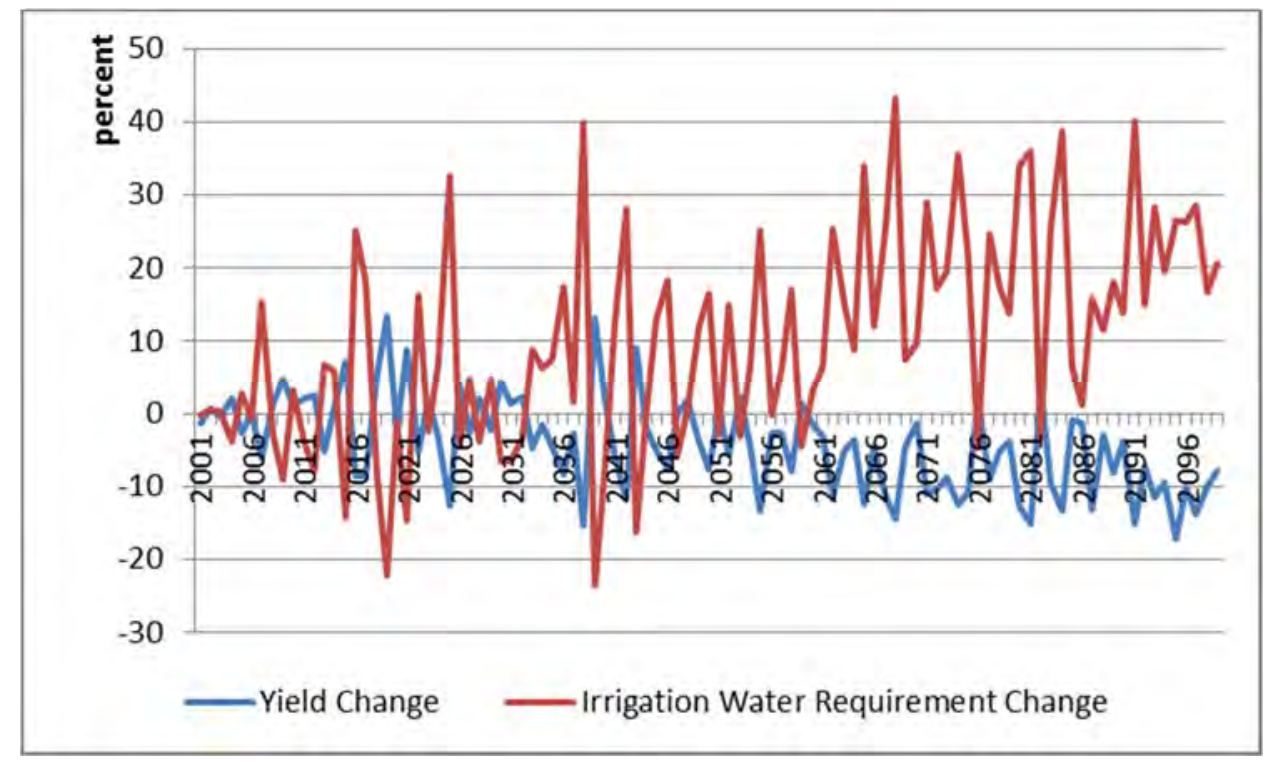

Source: Authors' calculations.

A more accurate way to look at these yield changes is considering them as drawn from a probability distribution. In that case climate change will affect the mean and standard deviation of the distribution of yield changes. Effects on the economy for each period will also be drawn from a probability distribution. Figure 4 shows the estimated probability density ${ }^{2}$ of the yield shocks for the periods mentioned above.

The distribution of yields shifts to the left, indicating lower means for the yield shocks. The spread of the distribution, which is related to the climate risk, is also higher in the second and third periods compared to the first period. In the first period the distribution is centred on a zero median and almost zero mean with extreme events in the range of \pm 10 per cent. In the second period the mean is not affected much and shifts towards -3 per cent. However, the frequency of

\footnotetext{
2 Kernel density estimation graphs are used to visualize this approach. Kernel density estimations are smoothing methods to estimate the probability density function. We follow the methods developed in Silverman (1992) to estimate the probability distributions from the model results.
} 
the extreme events increases with higher probabilities assigned to the negative extremes. Distribution of the yield changes spans between -15 and +10 per cent in the second period. In the last period this pattern becomes quite significant together with a substantial decline in mean and median. Hence, it can be concluded that climate change will both decrease the mean of the yields and increase the risk of extreme events, causing significant decline in yields.

Figure 4: Distribution of yield shocks

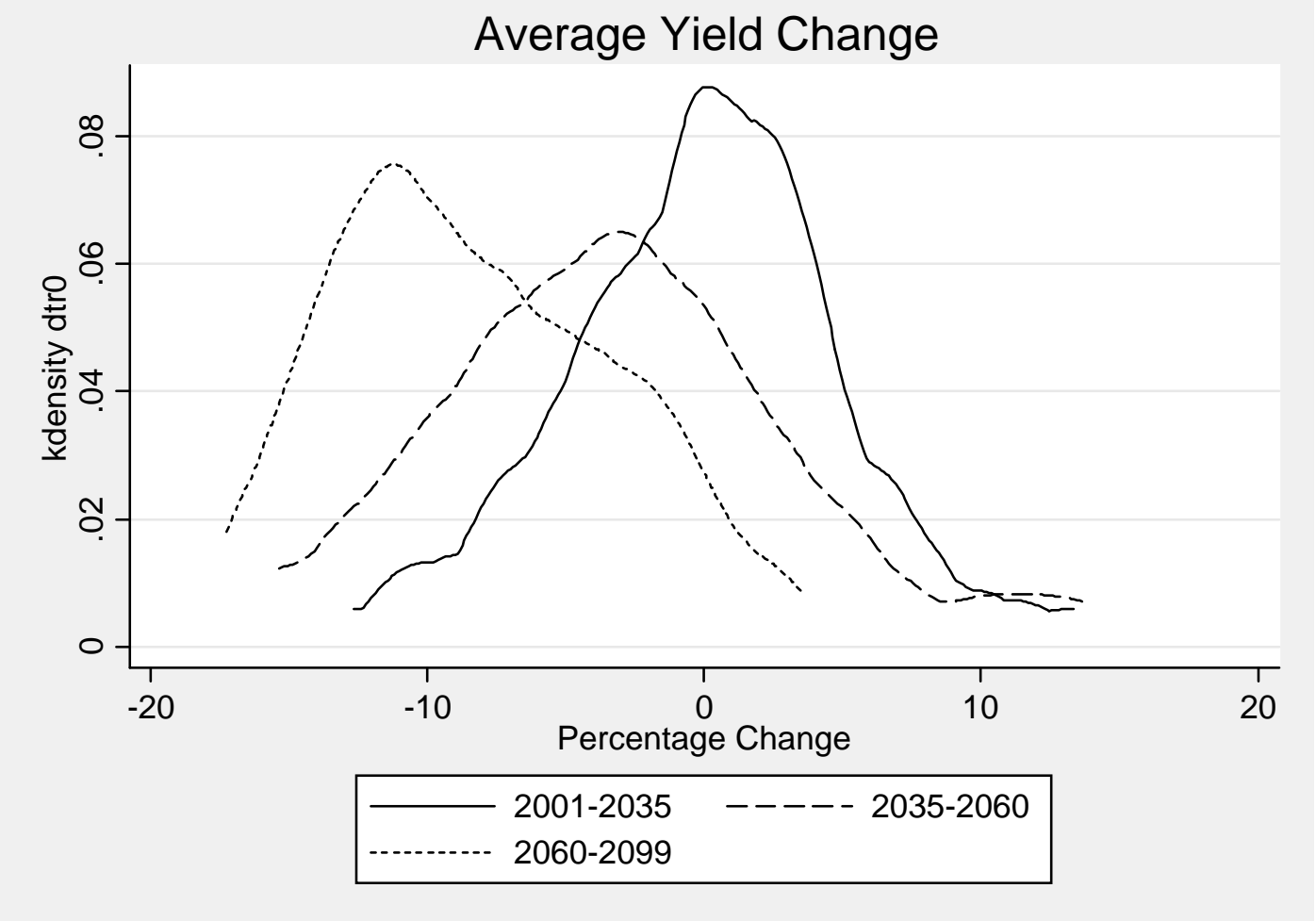

Source: Authors' calculations.

The spatial patterns of yield and irrigation requirement changes are given in Figure 5 for the periods 2010-35, 2035-60 and 2060-99 and the corresponding kernel density graphs can be found in Figure A1 in the Appendix. The spatial variation of the effects is also significant. In the western regions, yields increase and irrigation requirements decline in the first period. That is, western regions are generally better off during the first period. In the central regions, the change in yields is generally small with lower irrigation requirements. The eastern parts, on the other hand, are likely to experience an increasing water requirement and slight declines in the yields starting from the first period.

In coastal zones, central regions and eastern parts of the country, the effects of climate change differ significantly in the second period. In the coastal regions, yield changes are not significant, except in Thrace, and irrigation requirements increase slightly. Eastern parts of the country become slightly worse off with lower yields and higher irrigation requirements. However, central regions are heavily affected by climate change. Average yield loss exceeds 10 per cent for some provinces, while the decreasing trend in irrigation water requirements in the first period is completely reversed.

The difference in the effects of climate change becomes significant on the north-south axis, rather than the east-west axis. Furthermore, although the changes in yields and irrigation requirements follow approximately the same spatial pattern in the first two periods, they follow completely different patterns in the third period. The provinces that suffer from high yield loss 
form a belt-like shape starting from Thrace, extending through the northern parts of the central regions and ending in the central parts of the eastern regions. The increase in the irrigation requirement is higher in the northern regions, especially in the central regions and Thrace.

Figure 5: Spatial effects of climate change

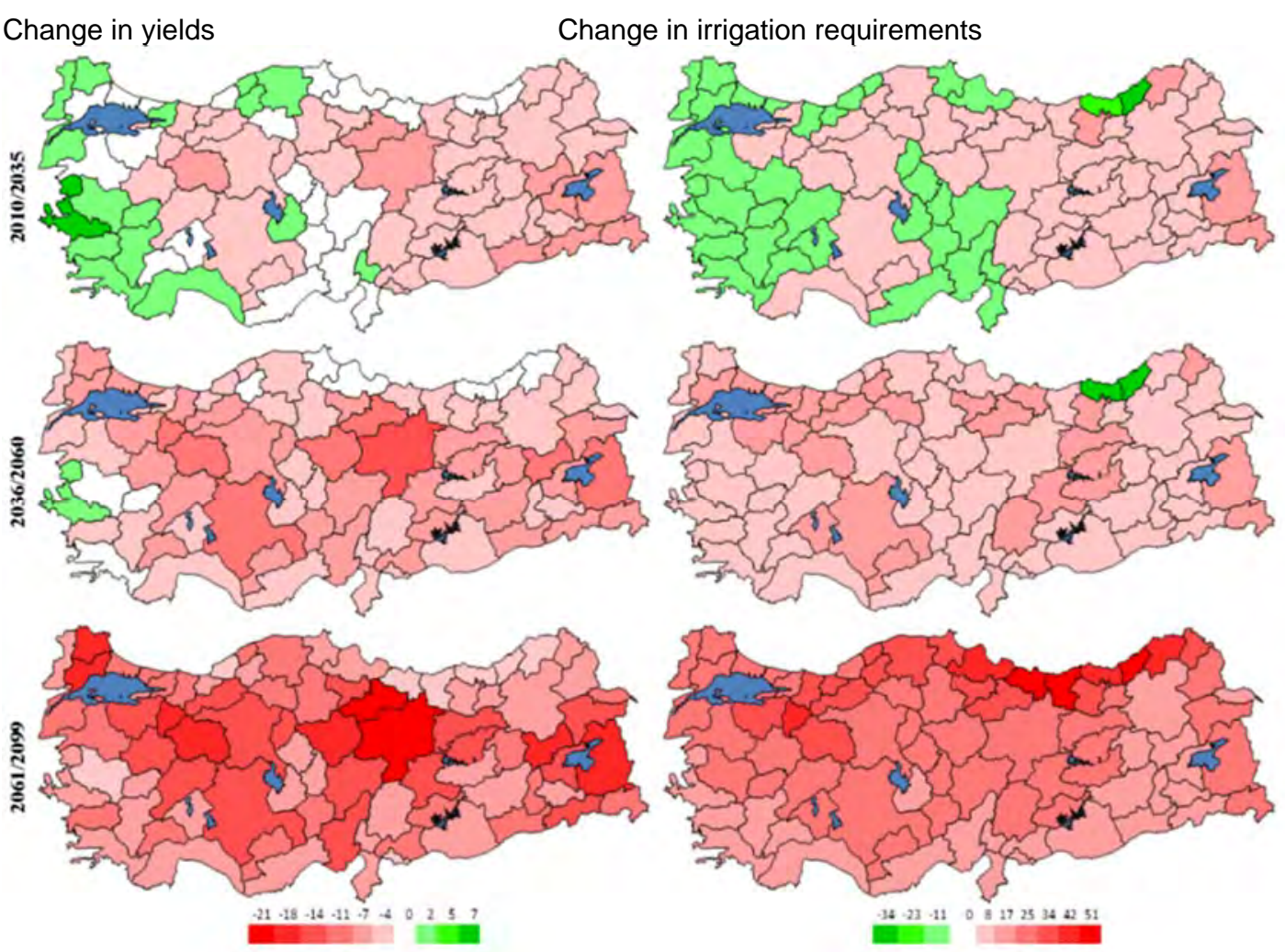

Source: Authors' calculations.

Our results support the findings of the other studies in the literature, both at the national and global levels. The effects become more significant after the 2060s. Furthermore, the effects are significant for all periods in some regions. Results also show that the variation in yields is higher than the variation in climatic conditions. This suggests that agricultural production is more prone to climatic changes and the risks related to it. Lastly, as predicted by many studies, the technical conditions become more favourable for agricultural production at the early stages of climate change when the increase in the mean temperature is below $2{ }^{\circ} \mathrm{C}$.

\subsection{Regional computable general equilibrium model}

The Walrasian CGE model developed in this study disaggregates the economy into seven activities producing commodities for seven sectors in each of the 12 NUTS-1 regions. The activities are agriculture, food production, textiles, other manufacturing, energy, public services and private services. The production structure of the activities is presented in Figure 6 . We use a three level nested production function that aggregates different factors and inputs at different levels.

Water is introduced as a factor of production as a perfect complement to the irrigated land. Hence we introduced a Leontief nest to the production function. The composite factor that is produced at this nest enters into a constant elasticity of substitution (CES) production function with other factors. Finally, this second composite value added is introduced into a new CES nest with a composite intermediate input. The composite intermediate input is produced by a 
Leontief nest. Since water and irrigated land are perfect complements, the price of the water-land composite is a weighted sum of the prices of water and irrigated land and the weights are the Leontief coefficients.

Figure 6: Production structure of the model

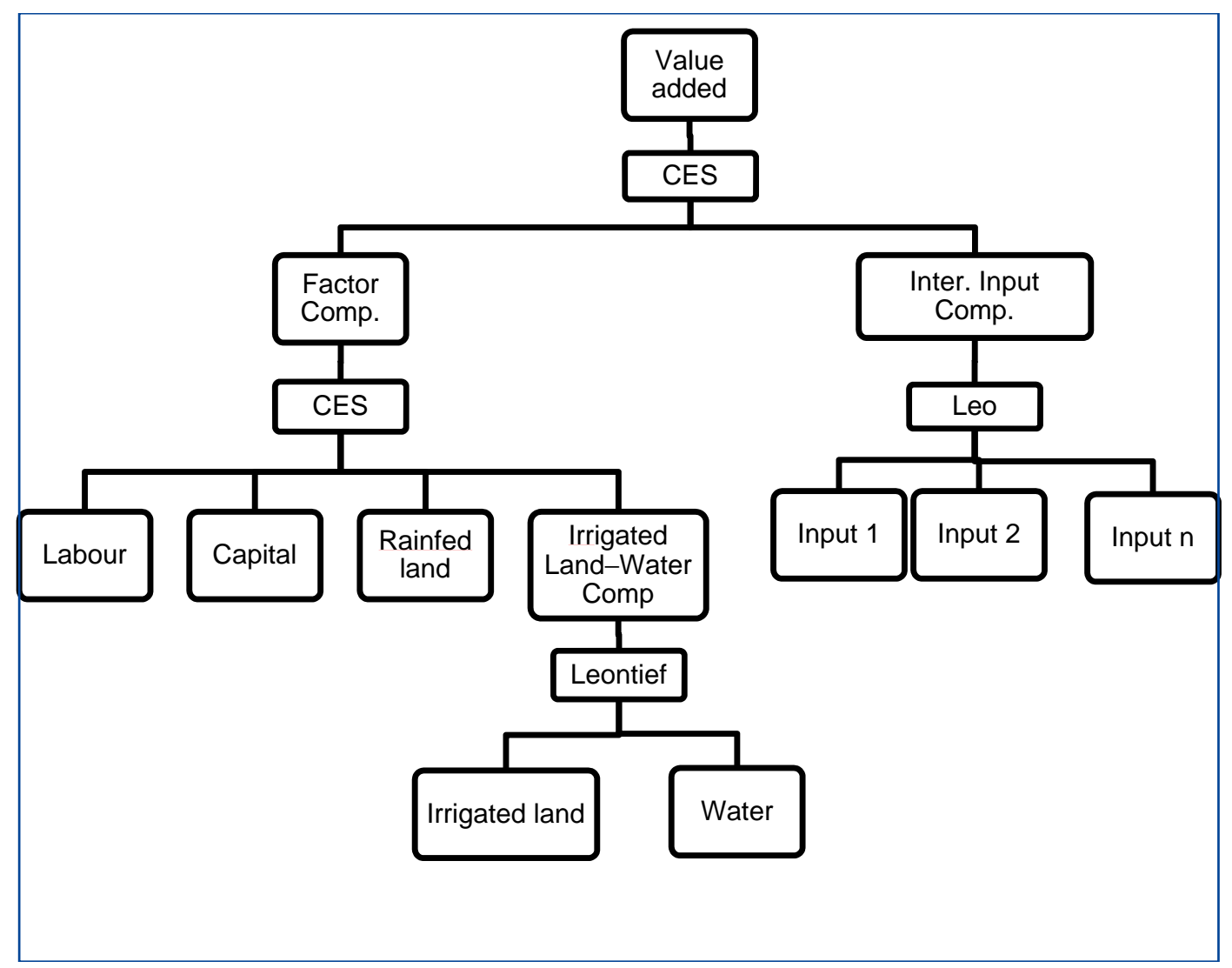

Source: Authors' illustration.

Only agriculture uses irrigated and rainfed land in production. Hence there is no additional Leontief nest of water-land composite for the other sectors. However, water is employed by all sectors. Water enters directly into the value added nest with labour and capital.

There is only one type of household in each region. The income generated by factors in a region is distributed to households in the same region. Households receive income from labour, land and water, while capital income goes to firms. From this income, firms pay institutional taxes, make transfers to the rest of the world, and distribute the remainder to households together with transfers from the government. Households use their income for consumption, leisure, savings and taxes. Households maximize a linear expenditure system utility function to make consumption decisions. Leisure enters the utility function like any other commodity, while the wage income is included as a budget constraint. The utility maximization problem is:

$$
\begin{aligned}
& \max U_{r, h}=\beta_{0} \ln \left(L_{r, h}-\gamma_{0, r, h}\right)+\sum_{i=1}^{k} \beta_{r, i} \ln \left(Q H_{i, r, h}-\gamma_{i, r, h}\right) \\
& \text { s.t. } \sum_{i=1}^{k} P_{r, i} Q H_{r, i}+w_{r, h} L_{r, h}=E H_{r, h}+w_{r, h} L_{r, h}=w_{r, h} T_{r, h}+Y N L_{r, h}=Y_{r, h}
\end{aligned}
$$


where the indice $i$ denotes commodities, $r$ denotes regions and $h$ denotes the households. $Q H_{i, r, h}$ is household demand for commodity $i, Q F S_{r, h}$ is labour supply, $U_{r, h}$ is unemployment, $L_{r, h}$ is leisure, $P_{r, i}$ is commodity prices, $w_{r, h}$ is the wage rate of labour, $E H_{r, h}$ is total household consumption spending, $T_{r, h}$ is the total number of working-age individuals in a household. $Y N L_{r, h}$ is non-labour income, $Y_{r, h}$ is total income. The above formulation suggests that households decide how many people should work to earn wages and how many of them may engage in leisure. Unemployment is determined in the labour market as the difference between labour supply and labour demand. We assume that unemployed people neither enjoy leisure nor receive wages.

The analytical solution of this problem yields the following demand functions

$$
\begin{aligned}
& Q H_{i, r, h}=\gamma_{i, r, h}+\frac{\beta_{i, r, h}}{\left(1-\beta_{0, r, h}\right) P_{r, i}}\left(E H_{r, h}-\sum_{i=1}^{k} P_{i, r} \gamma_{i, r, h}\right) \\
& Q F S_{r, h}-U_{r, h}=T_{r, h}-\gamma_{0, r, h}-\frac{\beta_{0, r, h}}{\left(1-\beta_{0, r, h}\right) w_{r, h}}\left(E H_{r, h}-\sum_{i=1}^{k} P_{r, i} \gamma_{i, r, h}\right)
\end{aligned}
$$

In the above equations, $T_{r, h}-\gamma_{0, r, h}$ is the total working-age population and it is not adjusted for wages since the household cannot control the total population $T_{r, h}$ nor the parameter $\gamma_{0, r, h}$. Hence, following Thurlow (2008), we introduce the following 'rule of motion' for the total available working-age population

$$
\frac{T_{r, h, t}-\gamma_{0, r, h, t}}{T_{r, h, b}-\gamma_{0, r, h, b}}=\left(\frac{w f r_{r, t} / c p i_{t}}{w f r_{b} / c p i_{b}}\right)^{\eta}
$$

where $t$ denotes post-simulation values and $b$ denotes the base-run values, $w f r$ is wage rate and cpi is the consumer price index. Accordingly, an increase in the real wage rate increases the total available working-age population, and vice versa.

The government receives tax income from activities, commodities, firms and households as well as transfers from the rest of the world. This income is used for government consumption, transfers to households and firms, government savings and transfers to the rest of the world.

Production activities make payments to commodity accounts for intermediate inputs, to factors such as wage payments and to government as net taxes. They receive payments from commodity accounts in exchange for the supply of goods and services. Commodity accounts also make payments to the rest of the world for imports and to government for indirect taxes. They receive payments from households for consumption of goods and from the rest of the world for exports.

Model closure rules follow conventional neoclassical assumptions. Since simulations are designed to account for the long-term climate change effects, it is assumed that the price of capital and land is fixed while their supply and demand adjust to the new equilibrium. Water is assumed to be fully employed and mobile among activities within a region and its supply is fixed. Demand 
for water adjusts to the new equilibrium. The consumer price index is the numéraire and hence is fixed while the domestic producer price index adjusts to clean the markets. We use a balanced closure rule for the savings-investment market. Investment is a fixed share of absorption, and marginal propensity to save is scaled to equalize savings and investments. The exchange rate is fixed by allowing foreign savings to adjust to keep the current account in balance. The share of government demand in total absorption is also fixed. Lastly, government savings are fixed, while direct tax rates are flexible and are scaled for households and firms to sustain the balance of government accounts. Further discussion of closure rules can be found in Lofgren et al. (2002).

\section{$4 \quad$ Description of data and simulations}

The aggregate version of the social accounting matrix (SAM) used in the analysis follows from Yiğiteli (2010) who presents a national SAM of the Turkish economy for the year 2008. The SAM developed by Yiğiteli (2010) consists of 49 production activities, which produce 49 commodities using formal and informal labour, land and capital. It has five household types differentiated according to income groups. We used various data sources to regionalize the 2008 National SAM into 12 NUTS-1 regions.

The I/O table used in this model is a regionalized version of the $2002 \mathrm{I} / \mathrm{O}$ table published by TurkStat (2011a). The Augmented Flegg Location Quotients (AFLQ) method (Flegg and Webber 2000) is used to regionalize the 2002 National I/O table by using regional data on employment. The latest regional employment data available for all sectors of the model are for 2002. Hence the shares of each region in each sector are used to interpolate 2008 employment figures across regions. These employment figures are in turn used in the AFLQ formula as described in Flegg and Webber (2000)

$$
A F L Q_{i, j}^{R}= \begin{cases}\frac{E_{i}^{R} / E_{j}^{R}}{E_{i}^{N} / E_{j}^{N}} \log _{2}\left(1+\frac{\sum_{i} E_{i}^{R}}{\sum_{i} E_{i}^{N}}\right)^{\delta} \log _{2}\left(1+\frac{E_{j}^{R} / \sum_{j} E_{j}^{R}}{E_{j}^{N} / \sum_{j} E_{j}^{N}}\right) & \text { if } \frac{E_{i}^{R} / \sum_{i} E_{i}^{R}}{E_{i}^{N} / \sum_{i} E_{i}^{N}}>1 \\ \frac{E_{i}^{R} / E_{j}^{R}}{E_{i}^{N} / E_{j}^{N}} \log _{2}\left(1+\frac{\sum_{i} E_{i}^{R}}{\sum_{i} E_{i}^{N}}\right)^{\delta} & \text { if } \frac{E_{i}^{R} / \sum_{i} E_{i}^{R}}{E_{i}^{N} / \sum_{i} E_{i}^{N}} \leq 1\end{cases}
$$

where $E_{i}^{R}$ is employment in sector $i$ of region $R$, and $E_{i}^{N}$ is national employment in sector $I$, while $\delta$ is a constant assumed to be 0.3 following Flegg and Webber (2000). $a_{i j}^{R}$ denotes the element of the I/O table in ith row and jth column, calculated as

$$
a_{i, j}^{R}=a_{i, j}^{N} \cdot A F L Q_{i, j}^{R}
$$

where $a_{i, j}^{N}$ is the national I/O share.

After calculating new regional I/O shares, further adjustments are made in the SAM. First, the regional coefficients do not necessarily add up to one for an activity in a region; that makes the $\mathrm{I} / \mathrm{O}$ table unbalanced. To keep the balance of I/O columns, it is assumed that the deficiency (or excess) in the row sum of the regional I/O table is due to the missing intermediate input trade among regions. Hence the intermediate input trade among regions that makes the $\mathrm{I} / \mathrm{O}$ table consistent is calculated by assuming that the intermediate input flow from one (exporting) region 
to another (importing) region is proportional to the share of the exporting region in national production. Second, the row sums of the I/O table do not necessarily add up to regional production figures. Hence, regional production figures are adjusted according to a new $\mathrm{I} / \mathrm{O}$ table. The imbalance in the commodity accounts, which is caused by this operation, is in turn balanced by introducing inter-regional trade.

Inter-regional trade is the key economic link among regions. Since the data on inter-regional trade are scanty, it is calculated for the purpose of this analysis. The discrepancy between the production and consumption of a region needs to be supplied by other regions to keep the SAM balanced. In doing so, it is assumed that every region's supply of commodities to the other regions is proportional to the former's share of national production. That is to say, differences in transportation costs among different regions are ignored. Regions where production exceeds consumption are assumed to consume only their own products and export the remainder to other regions. For importing regions, the imported amount is subtracted from the region's production to keep the balance between consumption and production. In other words, we assume that inter-regional trade occurs between producers of exporting and importing regions and wholesalers of importing regions. Hence, the value added produced in a region also includes the value of commodities obtained by trade. A better alternative would have been introducing inter-regional trade through households but due to lack of data this option is not viable for the current model. $^{3}$

The need for intermediate input and commodity trade among regions can be elucidated with an example. Istanbul, namely TR1, is characterized by high industrial employment and production with limited agricultural employment and production. However, the consumption of agricultural products is significantly higher than their production in Istanbul due to the population size. Istanbul is unable to satisfy its consumption requirements. Hence, the discrepancy in regional supply and demand is assumed to be supplied by other regions, according to the share of the latter in national production. That is, a region with higher agricultural production supplies more agricultural commodities to Istanbul.

The need for inter-regional trade in intermediate goods can also be explained in the context of agricultural production in Istanbul. Istanbul has significant manufacturing production and therefore produces agricultural inputs. However, since Istanbul produces small quantities of agricultural products, either the intermediate input use of the agricultural sector in Istanbul needs to be unrealistically high or some of the intermediate inputs need to be exported to other regions. The distribution among regions is again proportional to the production of the exporting region. By following this logic we create a bilateral intermediate input and commodity trade matrix.

The value added for water is calculated from the rent differentials obtained from the Quantitative Household Survey of G\&G Consulting et al. (2005). Data for the 1,356 farm households are used to calculate the rent for irrigated and rainfed land at NUTS-1 level. Average rental rate per hectare in 2004 is projected to 2008 by assuming that the change in rent would be the same as the change in the wholesale price index for the agricultural sector, which is approximately 32 per cent between 2004 and 2008. The difference between the rental rates of irrigated land and rainfed land was attributed to the irrigation, and hence that difference was used

3 This inter-regional trade is neutral in the sense that we do not introduce any behavioural assumptions for wholesalers. They only transport the goods of the exporting region to the suppliers of importing regions and there is no transaction cost in the process. Further, we also assume that the commodities from different regions are perfectly substitutable. 
as the price of water. The value added of water in the agricultural sector is calculated by multiplying the rent difference with the area of irrigated land. The payments from other sectors to water factors are calculated from the TurkStat Municipality Water Statistics (TurkStat 2011a).

Regional employment shares for each sector are obtained from the Annual Industry and Services Statistics (TurkStat 2011b). Then, national employment figures reported in the Regional Household Labor Force Statistics (TurkStat 2011c) for each sector are distributed to the regions by using these shares. The total working-age population is based on the number of people between 14 and 65 years of age. Regional unemployment figures are also obtained from the Regional Household Labor Force Statistics (TurkStat 2011c).

Regional disaggregation of the trade figures was done by using TurkStat's Regional Foreign Trade database for 2008 (TurkStat 2010c). Agriculture, energy, manufacturing and services are disaggregated directly by using the shares of regions in the trade of these sectors. Regional trade data for food and textiles are not available. Hence, the trade figures of regions are adjusted by taking into account the region's share in national production of the relevant sector and its share in manufacturing trade. The formula used is as follows:

$$
v_{R}=\frac{X_{Q \in R}}{\sum_{R} X_{R}} \frac{Y_{Q \in R}}{\sum_{R} Y_{R}} / \sum_{S} \frac{X_{S \subset R}}{\sum_{R} X_{R}} \frac{Y_{S \subset R}}{\sum_{R} Y_{R}}
$$

where $v_{R}$ is the regional share, $X$ is a region's production in the sector and $Y$ is the volume of the region's manufacturing trade. Shares that are less than 1 per cent are ignored. For imports, the region's share in manufacturing trade is directly used for adjustment.

Yiğiteli (2010) assumed a constant rate of tariff for all commodities. Tariffs are recalculated from the average applied tariff rates at HS6 level for 2008 (Ministry of Customs and Trade 2011).

Consumption is disaggregated according to TurkStat (2010b), which reports the distribution of household consumption according to regions and income quintiles. Households are not allowed to consume commodities from other regions. Government consumption is distributed according to the 2008 Public Accounts Bulletin (General Directorate of Public Accounts 2010a). Government consumption in each sector is distributed according to the region's share of total government expenditure on goods and services. Transfers are also distributed according to the 2008 Public Accounts Bulletin (General Directorate of Public Accounts 2010b). On the other hand, investments in different sectors are distributed according to the region's share of value added.

Factor incomes are distributed according to the regions' shares in factor value added. However, since capital income is distributed to regional firms, an adjustment is made in the capital account to keep the SAM balance intact. Firm income is then distributed to households, government, and the rest of the world as rent income, taxes and transfers, respectively. The imbalance in the firm account is balanced by increasing government transfers to the firm. Since this difference is generally small, the balancing procedure is not likely to affect the model results. 
Profit transfers to abroad and workers' remittances from the rest of the world are distributed according to the regions' shares of national capital income. ${ }^{4}$ The number of people receiving pensions per region, as reported by the Social Security Institution Yearbook 2008 (Social Security Institution 2010) is used to distribute the transfers from SSI to households. Other transfers from government to households are distributed according to each region's share in the total transfers as reported in the Social Assistance and Solidarity Fund annual report (2010). Government savings and payments made to the rest of the world by government, as well as the tax incomes of government are not distributed since these accounts are national. The tax payments of domestic institutions are distributed according to data reported by the General Directorate of Public Accounts (2010a). Regions' shares are calculated using accrued tax amounts.

Some minor adjustments are made in the SAM to eliminate very small trade figures that appear in the energy trade of the north-western and central regions as well as the food trade of the eastern regions. Small exports are added to the savings-investments (S-I) account, while import taxes are deducted from the S-I account. A similar adjustment is conducted for inter-regional trade. Accordingly, small inter-regional trade is eliminated by moving these figures to the production of consuming regions. Then the difference is added to the S-I account. The sum of the moved figures is added to the government savings accounts and discounted from the transfers made to the government from the rest of the world. The I/O table is also adjusted for small figures. Small figures flowing from agriculture to energy and to private and public service commodities are added to the labour value added. The increase in the income generated by labour is distributed to households. Then the household consumption is increased respectively to balance the commodity accounts.

The climate change scenario is simulated by simultaneously shocking the average yield and irrigation water requirements at the NUTS-1 level. One important caveat about simulations is that they are static experiments derived from annual changes and hence the results lack any dynamic feedback effects.

\section{$5 \quad$ Results and discussion}

Simulation results suggest that the effects of climate change on the economy will be quite significant. ${ }^{5}$ Table 1 shows the effect of climate change on the main macroeconomic variables. Welfare indicators such as absorption and household consumption do not change significantly in the first period, but worsen in the second and third periods. The change in the second period is likely to be caused by the years with extreme conditions, while the changes in the third period are due to decline in the average technical conditions of agriculture. Although the maximum values are close to the first period, the minimum values are significantly lower. This implies that the effects of climate change in the second period may be essentially attributed to the 'bad' years due to extreme climatic events, which in turn affect the economy adversely. In the third period, the negative effects become considerably higher, with vast declines in maximum values and relatively small declines in minimum values. This suggests that, in the third period, the effects of climate change will not only be felt through the extreme events but the average conditions will also

\footnotetext{
4 The method of distribution of remittances from abroad does not have a significant effect on the model, since the share of remittances in household income is only about 0.2 per cent.

${ }^{5}$ We run statistical tests to see if the mean and variance of the total production differ across the periods. The difference between the average changes in the production value of all sectors among periods is statistically significant at the 5 per cent significance level.
} 
worsen. The effect on foreign savings and the ratio of other macro indicators to the GDP is insignificant. This implies that the change in these indicators is parallel to the change in GDP.

Table 1: Effects on selected aggregate variables

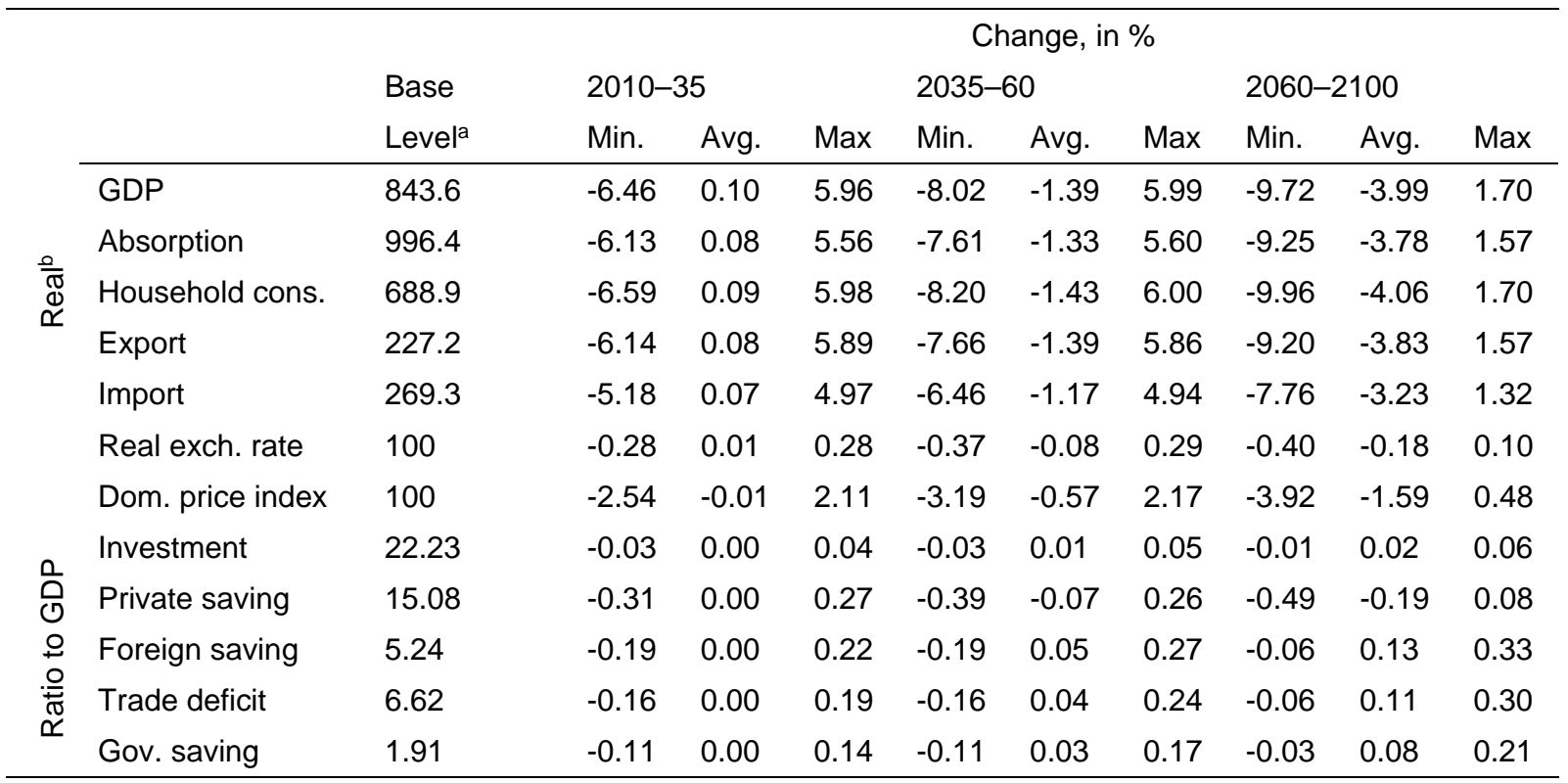

Notes: a Base level values are in billion Turkish Lira (TL); ${ }^{b}$ Values measured with 2008 prices.

Source: Authors' calculations.

The risk associated with the climate change is illustrated by the spread of change in GDP over three periods in Figure 7. The risk is relatively low with a mean and median around zero and higher probabilities assigned to relatively small changes in the first period. Hence the probability of observing a positive growth is high. In the second period, although the mean and median of the distribution do not change considerably, the probability assigned to the tails increases. Thus the probability of observing a negative change increases substantially. Finally, in the third period, the mean and median shift to -5 per cent while the spread increases. Hence, in the third period the probability of observing a positive change in GDP is very small. Consequently, climate change does not only decrease the average growth rate but also increases the frequency of extreme events. This has quite significant implications for climate policy. Adaptation under these circumstances implies reducing the adverse effects not only in the average but especially in negative extreme years. Hence this fact should be taken into account when making the cost benefit analysis for adaptation. 


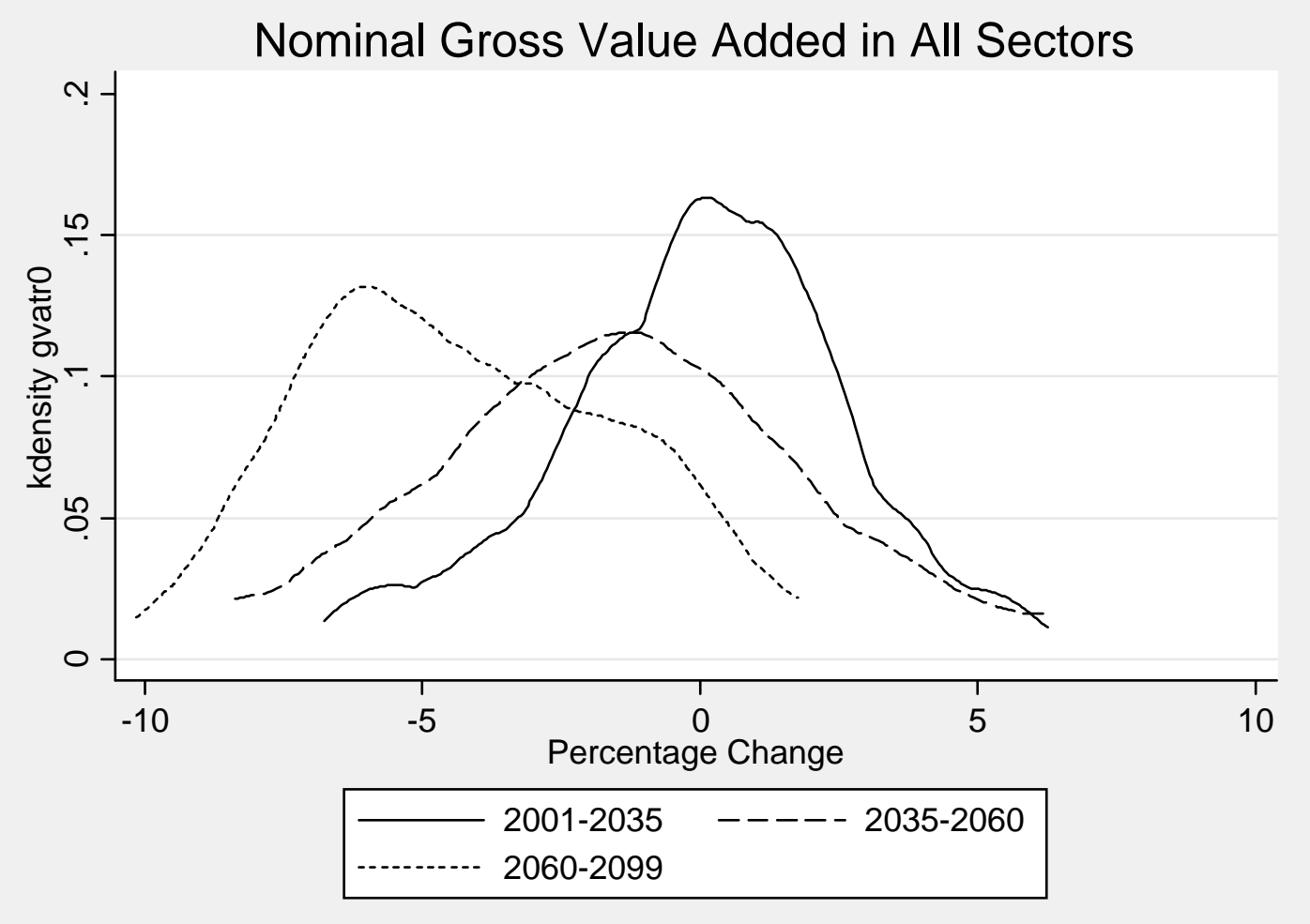

Source: Authors' calculations.

Table 2 shows the change in household income. The average change in household income is small for the first period while it becomes significant in the following periods. The difference between the average values gets wider in the second and third periods. Furthermore, the maximum and minimum values of the change in the household income differ significantly across regions. Accordingly, incomes of households in the western and central regions are more sensitive to extreme climatic conditions. This is mainly due to a significant decline in the prices of the factors that are more often employed by these regions, since the prices of capital and land are fixed and the share of water in the total income is quite small-the changes in household income are mainly driven by wages. The change in wages is in turn driven by the ability of firms to substitute water with labour in the non-agricultural sectors and with water-land composites in agriculture. Accordingly, the substitution is limited in Thrace, central Anatolia and eastern regions due to low water use in the base year. These regions benefit from the increase in the water price since income generated by water goes to households. This brings about an important feedback effect. The increase in the demand for water will drive the price of water up and this will compensate the loss in household welfare due to decreasing wages in these regions.

Table 2: Household income according to regions

\begin{tabular}{|c|c|c|c|c|c|c|c|c|c|c|}
\hline \multirow[b]{3}{*}{ NUTS1 } & \multirow{3}{*}{$\begin{array}{l}\text { Base } \\
\text { level }^{\mathrm{a}}\end{array}$} & \multicolumn{9}{|c|}{ Change in \% } \\
\hline & & \multicolumn{3}{|c|}{$2010-35$} & \multicolumn{3}{|c|}{$2035-60$} & \multicolumn{3}{|c|}{ 2060-2100 } \\
\hline & & Min. & Avg. & Max. & Min. & Avg. & Max. & Min. & Avg. & Max. \\
\hline TR1 & 212.4 & -11.13 & 0.13 & 10.44 & -13.80 & -2.50 & 10.45 & -16.49 & -6.90 & 2.67 \\
\hline TR2 & 41.9 & -3.94 & -0.14 & 4.21 & -2.20 & 0.09 & 2.04 & -3.95 & -0.04 & 2.66 \\
\hline TR3 & 117.6 & -7.71 & -0.15 & 6.58 & -9.65 & -1.87 & 7.36 & -11.60 & -4.98 & 1.36 \\
\hline TR4 & 87.8 & -7.86 & 0.10 & 7.25 & -9.82 & -1.71 & 7.39 & -11.81 & -4.92 & 1.73 \\
\hline TR5 & 89.1 & -8.28 & 0.09 & 7.64 & -10.32 & -1.81 & 7.73 & -12.52 & -5.16 & 1.78 \\
\hline TR6 & 100.3 & -5.74 & 0.10 & 5.35 & -7.17 & -1.18 & 5.54 & -8.88 & -3.61 & 1.30 \\
\hline TR7 & 38.3 & -2.35 & 0.15 & 3.63 & -2.32 & 0.17 & 2.81 & -3.38 & -0.45 & 1.45 \\
\hline TR8 & 46.7 & -4.32 & 0.06 & 3.93 & -4.70 & -0.98 & 3.07 & -5.57 & -2.30 & 2.77 \\
\hline
\end{tabular}




\begin{tabular}{lrrrrrrrrrr}
\hline TR9 & 29.8 & -2.80 & 0.05 & 2.82 & -3.72 & -0.80 & 2.26 & -4.45 & -1.92 & 0.19 \\
TRA & 21.1 & -2.37 & 0.75 & 5.55 & -3.46 & 0.69 & 5.44 & -3.53 & 2.17 & 7.93 \\
TRB & 35.2 & -1.02 & 0.88 & 3.41 & -2.49 & 1.54 & 3.78 & -1.10 & 2.94 & 6.05 \\
TRC & 70.2 & -1.35 & 0.00 & 1.03 & -1.43 & -0.22 & 1.10 & -2.01 & -0.80 & 0.81 \\
Turkey & 890.4 & -6.18 & 0.10 & 5.73 & -7.66 & -1.33 & 5.76 & -9.28 & -3.81 & 1.61 \\
\hline
\end{tabular}

Note: ${ }^{a}$ Base level values are in billion Turkish Lira (TL).

Source: Authors' calculations.

Climate change affects all sectors significantly, although the shocks are introduced only to agriculture. This is a result of complex interactions among the sectors. The significant change in food production can be explained by the fact that agricultural commodities are important intermediate inputs for this sector. However, this is not the only linkage between the sectors. All sectors compete for factors and hence a change in the factor demand in one sector affects all sectors. Second, the sectors also interact in the commodity markets. Since all commodities are substitutable in household demand, a change in the price of one commodity affects the demand for other commodities as well. Table 3 reports the state of commodity and factor markets. Details for the rest of the sectors can be found in Appendix Table A1. The average changes in the markets are not significant for the first period. There is a slight increase in production and consumption of all commodities while prices remain almost constant. The most important changes in international trade are observed in agriculture, food and the textile trade. Agricultural trade increases significantly due to the increase in exports. Despite the slight increase in imports, the trade balance improves.

Food and textile sectors follow the same trend, where exports increase more than imports. Imports and exports in the other sectors do not change significantly. The second significant effect in the first period is on water and irrigated land markets. Declining water requirements cause the price of water to decline and this, together with the increasing productivity of agriculture, drives the demand for irrigated land upwards.

Table 3: Sectoral results

\begin{tabular}{|c|c|c|c|c|c|c|}
\hline & & & \multirow{2}{*}{$\begin{array}{l}\text { Base } \\
\text { level }^{\mathrm{a}}\end{array}$} & \multicolumn{3}{|c|}{ Change, in \% } \\
\hline & & & & 2008-35 & 2035-60 & 2060-99 \\
\hline \multirow{15}{*}{ 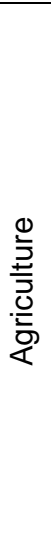 } & \multirow{3}{*}{ Market } & Prod. & 107.6 & 0.36 & -1.69 & -5.12 \\
\hline & & Cons. & 64.9 & 0.19 & -1.15 & -3.31 \\
\hline & & Prices & 1.00 & -0.07 & 2.58 & 7.30 \\
\hline & \multirow{5}{*}{ Employment } & Labour & 5.0 & 0.08 & 1.54 & 4.52 \\
\hline & & Irr. Land & 5.3 & 0.78 & -3.96 & -13.92 \\
\hline & & Rf. Land & 16.7 & 0.21 & 1.40 & 3.49 \\
\hline & & Capital & 55.0 & 0.03 & 1.20 & 3.23 \\
\hline & & Water & 1.9 & 0.00 & 0.00 & 0.00 \\
\hline & \multirow{5}{*}{ Wage } & Labour & 7.68 & 0.00 & -0.45 & -1.69 \\
\hline & & Irr. Land & 0.28 & 1.24 & 0.96 & 0.47 \\
\hline & & R. Land & 0.33 & -0.32 & -0.71 & -1.23 \\
\hline & & Capital & 1.09 & 0.00 & 0.00 & 0.00 \\
\hline & & Water & 1.00 & -1.56 & 8.04 & 26.63 \\
\hline & \multirow{3}{*}{ Trade } & Import & 9.1 & 0.02 & 5.86 & 15.60 \\
\hline & & Export & 5.8 & 3.53 & -5.76 & -19.80 \\
\hline \multirow{12}{*}{$\begin{array}{l}\text { ஜ } \\
\text { ㄴ }\end{array}$} & & Deficit & -3.4 & -6.00 & 25.78 & 76.32 \\
\hline & \multirow{3}{*}{ Market } & Prod. & 30.3 & 0.11 & -1.14 & -3.32 \\
\hline & & Cons. & 92.4 & 0.08 & -0.71 & -2.12 \\
\hline & & Prices & 1.00 & -0.06 & 0.64 & 2.05 \\
\hline & \multirow{3}{*}{ Employment } & Labour & 0.69 & 0.04 & -0.55 & -1.66 \\
\hline & & Capital & 21.1 & 0.14 & -1.37 & -3.99 \\
\hline & & Water & 0.13 & 0.03 & 0.15 & 0.40 \\
\hline & \multirow{3}{*}{ Wage } & Labour & 13.07 & 0.11 & -1.11 & -3.13 \\
\hline & & Capital & 1.00 & 0.00 & 0.00 & 0.00 \\
\hline & & Water & 1.00 & 0.17 & -1.98 & -5.74 \\
\hline & \multirow{2}{*}{ Trade } & Import & 5.4 & 0.04 & 1.40 & 3.74 \\
\hline & & Export & 9.3 & 0.41 & -3.89 & -10.97 \\
\hline
\end{tabular}




\begin{tabular}{|c|c|c|c|c|c|c|}
\hline \multirow{13}{*}{ 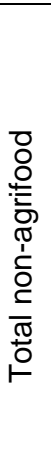 } & \multirow{4}{*}{ Market } & Deficit & 3.9 & 0.94 & -11.25 & -31.43 \\
\hline & & Prod. & 705.7 & 0.06 & -1.36 & -3.85 \\
\hline & & Cons. & 665.6 & 0.06 & -1.36 & -3.85 \\
\hline & & Prices & 1.00 & 0.01 & -0.51 & -1.41 \\
\hline & \multirow{3}{*}{ Employment } & Labour & 15.5 & 0.02 & -0.65 & -1.87 \\
\hline & & Capital & 428.8 & 0.11 & -1.76 & -5.00 \\
\hline & & Water & 3.8 & 0.00 & -0.01 & -0.01 \\
\hline & \multirow{3}{*}{ Wage } & Labour & 17.63 & 0.09 & -1.41 & -3.94 \\
\hline & & Capital & 1.00 & 0.00 & 0.00 & 0.00 \\
\hline & & Water & 1.00 & 0.16 & -2.22 & -6.35 \\
\hline & \multirow{3}{*}{ Trade } & Import & 275.9 & 0.09 & -2.06 & -5.69 \\
\hline & & Export & 212.1 & 0.00 & -1.80 & -4.87 \\
\hline & & Deficit & -63.7 & 0.40 & -2.95 & -8.43 \\
\hline
\end{tabular}

Notes: a Production, consumption and quantity of water are expressed in terms of value added units, i.e. units that make base prices 1. Labour is in million persons. Rest of the base values are in billion TL.

Source: Authors' calculations.

The effects are reversed and become significant in the second and third periods. All sectors suffer from a serious fall in production. The decline is higher in agriculture. Consumption of all commodities also falls. For the agriculture and food sectors, decreasing household incomes and increasing domestic prices underlie the decline in consumption. That is to say, income and substitution effects work in the same direction for these sectors. For the rest of the sectors, income and substitution effects work in the opposite direction. Declining household incomes lower consumption while declining relative prices increase it. Consequently, the decline in consumption is milder in non-agrifood sectors while it is higher for agriculture.

Agricultural and food prices increase while prices in the other sectors decline in the second and third periods. Price changes get higher in absolute values throughout the periods. The increases in agricultural and food prices are supply-driven. Agricultural production falls due to the decline in agricultural productivity, which decreases the supply of agricultural products and drives agricultural prices up. This causes a negative supply shock in food production for which agricultural products are important intermediate inputs. Consequently, food prices also increase. Since all prices are relative to the consumer price index, the price of other commodities declines.

The effects on factor markets in the last two periods occur mainly through the price of water and employment of irrigated land for agriculture. For the other sectors, capital plays a more significant role. An increase in irrigation requirements boosts demand and the price of water since its supply is fixed. Consequently, farmers decrease their demand for irrigated land, which is a perfect complement with water. Other factors are mobilized towards agriculture to compensate for the decreasing total factor productivity and water productivity. Hence, capital, rainfed land and labour employment in agriculture increase. In the other sectors, there is significant decline in the use of capital and employment. Labour and capital prices also fall since firms lay off labour due to decreasing production. Some of this labour is absorbed by agriculture with lower wages.

In the last two periods, trade is affected significantly by climate change. As production falls, imports increase and exports decline in both the agricultural and food sectors. For the rest of the sectors, both imports and exports decline despite falling prices. These changes are driven by income and substitution effects among imported and domestic goods. For agriculture and food products, income and substitution effects work in opposite directions: since imports become relatively cheaper, demand for imported goods is favoured by substitution effects while falling household income lowers demand. For the rest of the sectors, since prices decline both effects work in the same direction: domestic goods become cheaper, and substitute imported goods, although lowering household income, also further reduce demand for imports. The trade deficit deteriorates in all sectors except manufacturing. This means that the decline in imports is proportionally smaller than the decline in exports for the non-agrifood sectors. The total trade 
deficit increases since manufacturing is the main trading sector with an 80 per cent share of imports and 60 per cent share of exports.

Figure 8 shows the spatial distribution of value added for the agrifood and other sectors. Although the effects in the first period are small for all sectors, there are some regional disparities. Agricultural production increases in the Mediterranean and Aegean regions, while it declines in south-eastern Anatolia. In the second period, west central regions and south-eastern regions are among the most affected. The Mediterranean region is relatively worse off although the effects are magnified for all regions in the third period. In the eastern regions, change in agricultural production is generally smaller, except for south-east Anatolia. In both periods, regions that are more dependent on irrigation are affected more. Thus, increase in irrigation water requirements is as important as the decline in yields in determining the final effect on agricultural production.

Figure 8: Regional production in value added units

Agrifood production
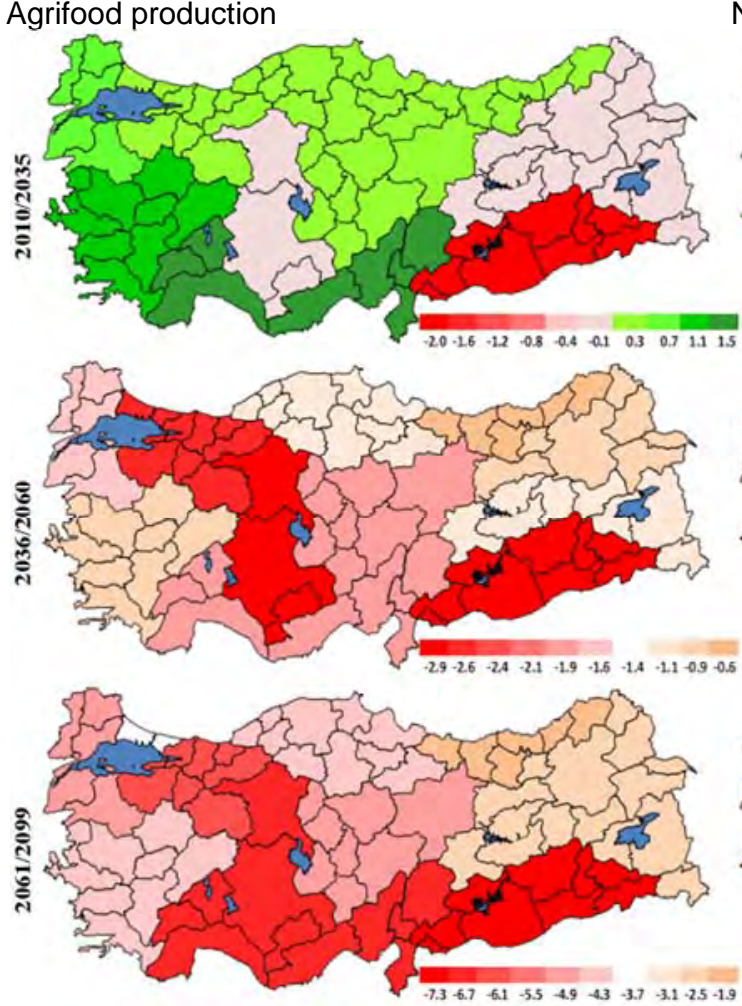

Non-agrifood production
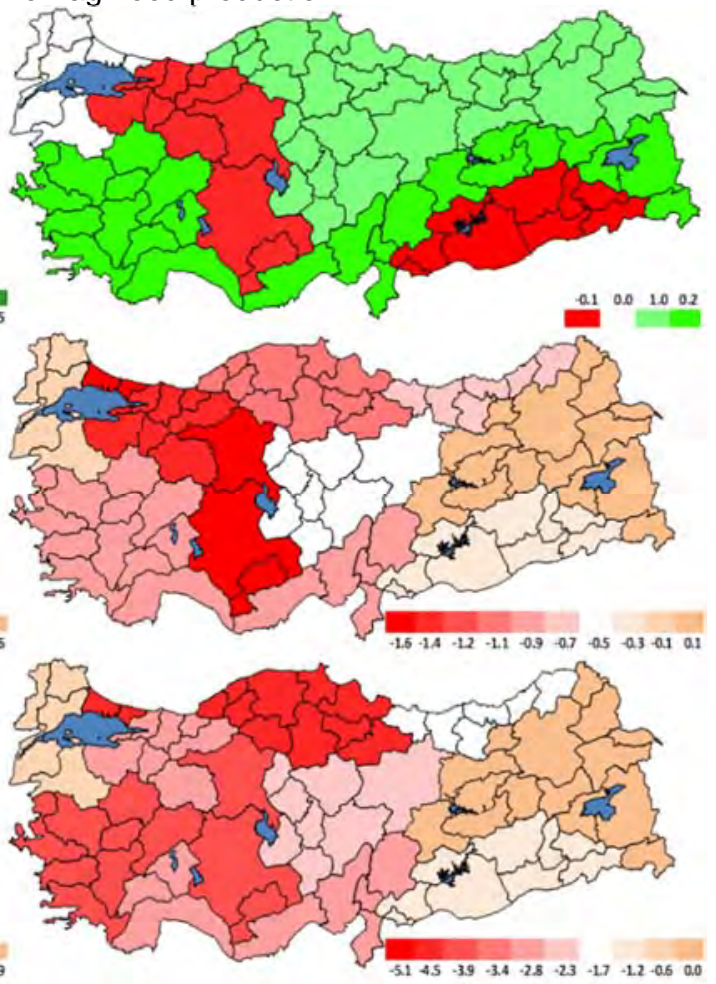

Source: Authors' calculations.

Effects on the production of non-agrifood sectors are determined by the strength of the link between agriculture and other sectors. The west central regions are affected significantly in the second period. In north-western and eastern regions, the effects are slightly positive due to the weak forward linkages of agriculture with the non-agrifood sectors. In coastal regions, the decline in production of non-agrifood sectors is generally higher in the third period, except in the eastern Black Sea region. In the Aegean region non-agrifood production declines quite significantly although the change in agricultural production is significantly milder. This suggests that non-agrifood sectors in the coastal regions can substitute agricultural inputs with other inputs up to a threshold, but once this threshold is exceeded, non-agrifood sectors become more vulnerable to climate change. The effects on the manufacturing and services sectors in the eastern regions are relatively small in both the second and third periods. This is mainly due to the weak link between agriculture and the rest of the economy in these regions. 
Turkey consists of regions that are quite diverse in terms of social and geographical structures. This is also reflected in the economy in the form of different consumption and production patterns. Distinct regional structures bring about a complicated network of economic relationships. In order to develop a solid understanding of plausible effects of climate change on the Turkish economy, one needs to take into account the interaction between different regional structures.

A CGE model that incorporates the regional diversity is used to discover the impact of climate change shock. Climate change is introduced in the form of changing agricultural productivity and irrigation requirements. A crop water requirement model is used to estimate these effects for the years 2010-99. The estimated values of changes in the climatic conditions were obtained from a regionalized global climate model. The results of the climate model suggest that the effects of climate change will become significant after 2035. The average climate conditions in the period between 2035 and 2060 will get worse, mainly due to increasing frequency of 'bad' years and higher irrigation requirements. On the other hand, the negative impact after 2060 will be caused mainly by deteriorating average conditions together with the increasing frequency of climatic extremes.

The effects of climate change on the economy will be witnessed through drastic changes both in agricultural production and in the relative prices of commodities. Production of agricultural and food commodities are severely affected by the shock, accompanied by considerable increase in their prices. Coastal regions are affected relatively less until the 2060s, then they are significantly worse off afterwards. In all periods, the effects on the regions that use less irrigation water are milder. This suggests that the increase in irrigation requirements is as important as declining yields. A similar pattern is also observed in welfare indicators. Households in the eastern regions are affected less.

The volume of trade declines severely after 2035 and the trade balance deteriorates in all sectors, except manufacturing. As a result, the total trade deficit decreases, thanks to the improved balance of trade in manufacturing. The need for agricultural and food imports becomes more severe and this may contribute to giving higher priority to food security in medium and longterm policy design.

Results presented in this study are compatible with the findings of other studies at national or global levels. The economic effects are region-specific. Hence, climate change adaptation policy needs to be region-specific but should also consider interaction between the regions. There are welfare gains in some regions and significant losses in others. Furthermore, the effects are also asymmetric among economic agents. As predicted by many studies, the effects become more significant after the 2030s, especially in the form of increasing frequency of extreme events. 


\section{Appendix}

\section{Supplementary tables and figures}

Figure A1: Kernel distribution of yield change for each region
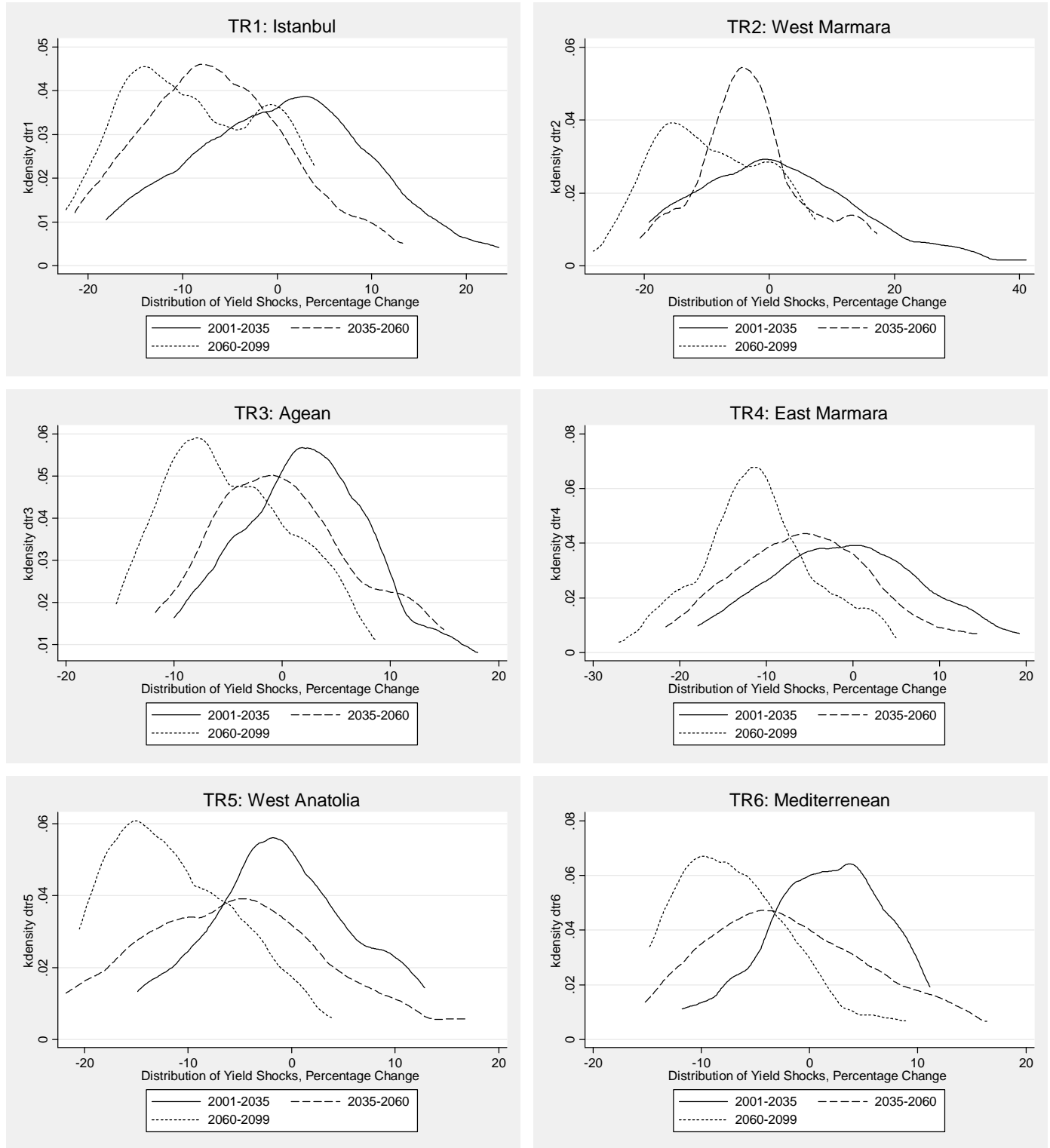

Source: Authors' calculations. 
Figure A1: Kernel distribution of yield change for each region (continued)
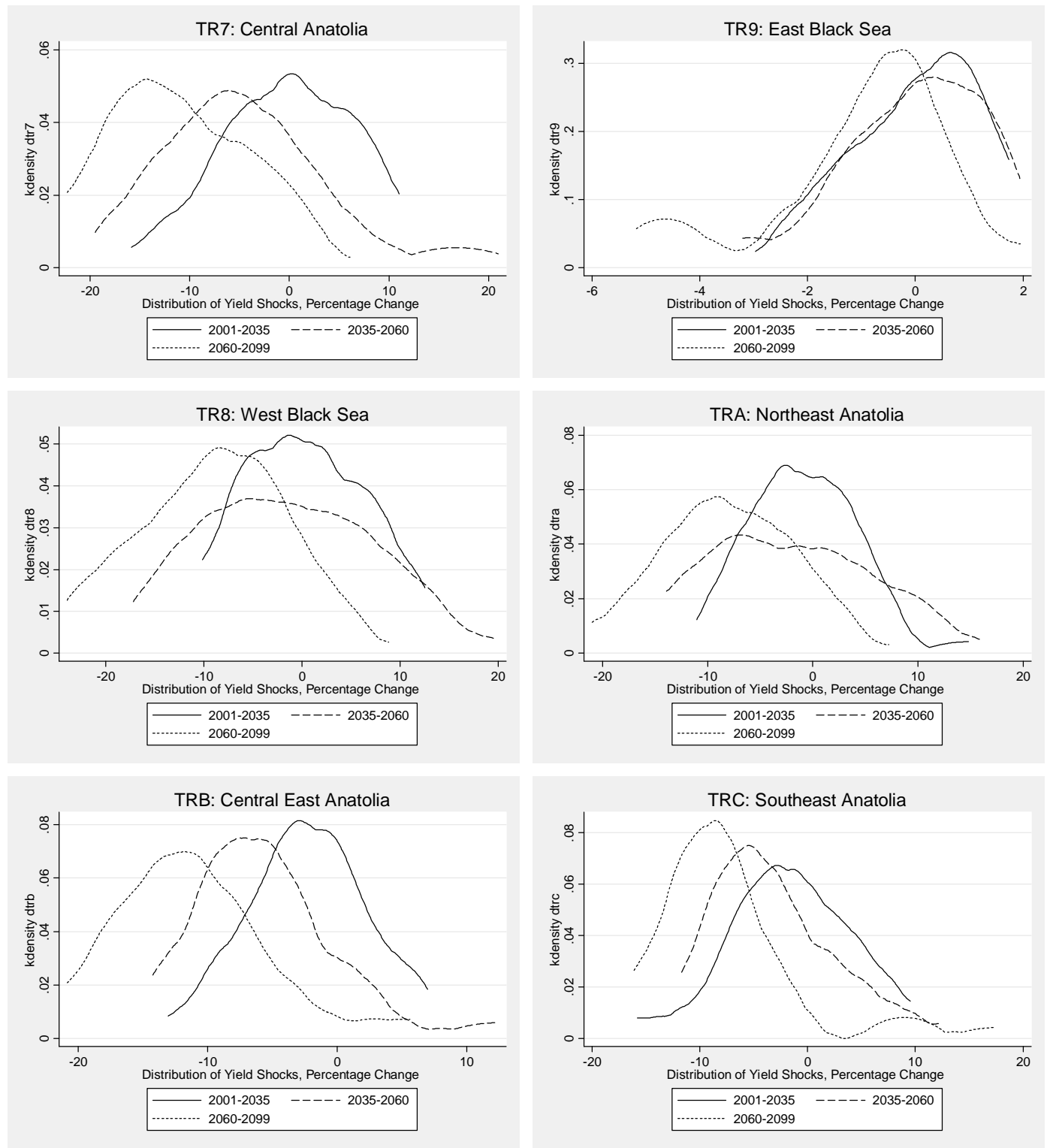

Source: Authors' calculations. 
Table A1: Effects on selected aggregate variables of other sectors

\begin{tabular}{|c|c|c|c|c|c|c|}
\hline & & & Base & 2010-35 & $2035-60$ & 2060-2100 \\
\hline \multirow{12}{*}{ 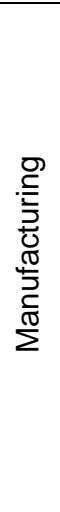 } & \multirow{3}{*}{$\frac{\dot{\nu}}{\stackrel{\vec{J}}{\Sigma}}$} & Prod. & 142,478 & 0.01 & -0.95 & -2.62 \\
\hline & & Cons. & 103,317 & 0.08 & -1.52 & -4.26 \\
\hline & & Prices & 1.00 & 0.01 & -0.60 & -1.65 \\
\hline & \multirow{3}{*}{$\frac{\dot{\frac{\alpha}{E}}}{\frac{\mathrm{w}}{\mathrm{m}}}$} & Labour & 3,179 & -0.01 & -0.39 & -1.06 \\
\hline & & Capital & 73,739 & 0.05 & -1.45 & -4.01 \\
\hline & & Water & 1,079 & -0.02 & 0.32 & 0.90 \\
\hline & \multirow{3}{*}{$\begin{array}{l}\stackrel{0}{\overparen{T}} \\
\stackrel{\pi}{3}\end{array}$} & Labour & 21.29 & 0.06 & -1.42 & -3.93 \\
\hline & & Capital & 1.00 & 0.00 & 0.00 & 0.00 \\
\hline & & Water & 1.00 & 0.15 & -2.27 & -6.38 \\
\hline & \multirow{3}{*}{$\begin{array}{l}\frac{0}{\frac{\pi}{0}} \\
\stackrel{\varpi}{\models}\end{array}$} & Import & 229,988 & 0.09 & -2.14 & -5.82 \\
\hline & & Export & 135,216 & -0.07 & -1.46 & -3.77 \\
\hline & & Deficit & $-94,772$ & 0.31 & -3.10 & -8.74 \\
\hline \multirow{12}{*}{ 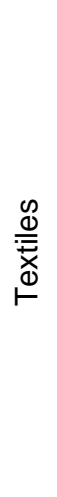 } & \multirow{3}{*}{ 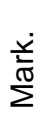 } & Prod. & 35,046 & 0.04 & -1.14 & -3.14 \\
\hline & & Cons. & 46,251 & 0.03 & -0.53 & -1.50 \\
\hline & & Prices & 1.00 & -0.01 & -0.44 & -1.19 \\
\hline & \multirow{3}{*}{$\begin{array}{l}\overline{\mathrm{E}} \\
\bar{w}\end{array}$} & Labour & 1,657 & 0.03 & -0.43 & -1.17 \\
\hline & & Capital & 22,141 & 0.06 & -1.53 & -4.24 \\
\hline & & Water & 186.857 & -0.01 & 0.21 & 0.64 \\
\hline & \multirow{3}{*}{ 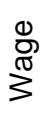 } & Labour & 7.68 & 0.03 & -1.48 & -4.11 \\
\hline & & Capital & 1.00 & 0.00 & 0.00 & 0.00 \\
\hline & & Water & 1.00 & 0.14 & -2.25 & -6.35 \\
\hline & \multirow{3}{*}{$\begin{array}{l}\frac{0}{\frac{\pi}{\pi}} \\
\stackrel{\varpi}{\models}\end{array}$} & Import & 11,830 & 0.04 & -0.90 & -2.44 \\
\hline & & Export & 32,308 & 0.06 & -2.23 & -6.03 \\
\hline & & Deficit & 20,478 & 0.07 & -3.00 & -8.11 \\
\hline \multirow{12}{*}{$\begin{array}{l}\text { ठे } \\
\frac{\bar{\omega}}{\bar{山}}\end{array}$} & \multirow{3}{*}{$\frac{\dot{v}}{\stackrel{\vec{*}}{\Sigma}}$} & Prod. & 14,031 & 0.06 & -0.94 & -2.68 \\
\hline & & Cons. & 12,786 & 0.05 & -0.75 & -2.13 \\
\hline & & Prices & 1.00 & 0.02 & -0.37 & -1.01 \\
\hline & \multirow{3}{*}{$\begin{array}{l}\overline{\mathrm{o}} \\
\bar{w}\end{array}$} & Labour & 161 & -0.05 & -0.46 & -1.26 \\
\hline & & Capital & 10,800 & 0.08 & -1.10 & -3.13 \\
\hline & & Water & 7.167 & -0.01 & 0.40 & 1.12 \\
\hline & \multirow{3}{*}{$\begin{array}{l}0 \\
\stackrel{\pi}{\pi} \\
3\end{array}$} & Labour & 20.09 & 0.16 & -0.88 & -2.58 \\
\hline & & Capital & 1.00 & 0.00 & 0.00 & 0.00 \\
\hline & & Water & 1.00 & 0.18 & -1.91 & -5.51 \\
\hline & \multirow{3}{*}{$\begin{array}{l}\frac{0}{\frac{\pi}{0}} \\
\stackrel{0}{\models}\end{array}$} & Import & 18.956 & 0.04 & -1.17 & -3.16 \\
\hline & & Export & 101 & 0.00 & -2.13 & -5.68 \\
\hline & & Deficit & 82 & 0.00 & -2.35 & -6.26 \\
\hline
\end{tabular}

Notes: Production and consumption figures and quantity of water are quantities in terms of value added units, i.e. units that make base prices. Labour is in thousand persons. Rest of the base values are in million TL.

Source: Authors' calculations. 
Table A2: Effects on selected aggregate variables of other sectors (continued)

\begin{tabular}{|c|c|c|c|c|c|c|}
\hline & & & Base & 2010-35 & 2035-60 & 2060-2100 \\
\hline \multirow{12}{*}{ 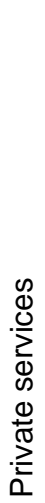 } & \multirow{4}{*}{$\frac{\dot{y}}{\stackrel{\vec{\sigma}}{\Sigma}}$} & Prod. & 429,450 & 0.09 & -1.61 & -4.51 \\
\hline & & Cons. & 326,497 & 0.09 & -1.85 & -5.14 \\
\hline & & Prices & 1.00 & 0.01 & -0.45 & -1.22 \\
\hline & & Labour & 10,012 & 0.03 & -0.77 & -2.22 \\
\hline & \multirow{3}{*}{$\frac{\dot{\bar{n}}}{\text { फ़ }}$} & Capital & 308,817 & 0.12 & -1.91 & -5.36 \\
\hline & & Water & 1,928 & 0.01 & -0.15 & -0.42 \\
\hline & & Labour & 11.86 & 0.09 & -1.55 & -4.26 \\
\hline & \multirow{3}{*}{$\begin{array}{l}\stackrel{0}{\overparen{D}} \\
3 \\
3\end{array}$} & Capital & 1.00 & 0.00 & 0.00 & 0.00 \\
\hline & & Water & 1.00 & 0.17 & -2.33 & -6.54 \\
\hline & & Import & 34,029 & 0.14 & -2.14 & -5.86 \\
\hline & \multirow{3}{*}{$\begin{array}{l}\frac{0}{0} \\
\stackrel{\sigma}{\circ} \\
\vdash\end{array}$} & Export & 44,558 & 0.16 & -2.59 & -7.30 \\
\hline & & Deficit & 10,529 & 0.21 & -4.05 & -6.00 \\
\hline & & Prod. & 84,707 & 0.02 & -1.07 & -2.96 \\
\hline & \multirow{3}{*}{ 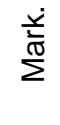 } & Cons. & 19,477 & 0.04 & -1.77 & -4.85 \\
\hline & & Prices & 1.00 & 0.08 & -0.73 & -2.07 \\
\hline & & Labour & 486 & 0.02 & -0.94 & -2.59 \\
\hline \multirow{5}{*}{ 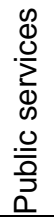 } & \multirow{3}{*}{ 亳 } & Capital & 13,306 & 0.14 & -1.71 & -4.84 \\
\hline & & Water & 573.957 & 0.01 & -0.22 & -0.59 \\
\hline & & Labour & 145.59 & 0.13 & -1.08 & -3.07 \\
\hline & \multirow{2}{*}{$\stackrel{0}{\mathbb{\pi}}_{3}^{\mathbb{\pi}}$} & Capital & 1.00 & 0.00 & 0.00 & 0.00 \\
\hline & & Water & 1.00 & 0.18 & -1.97 & -5.63 \\
\hline
\end{tabular}

Note: Production and consumption figures and quantity of water are quantities in terms of value added units, i.e. units that make base prices. Labour is in thousand persons. Rest of the base values are in million TL.

Source: Authors' calculations. 


\section{References}

Agrawala, S., and Fankhauser, S. (eds) (2008). Economic Aspects of Adaptation to Climate Change: Costs, Benefits and Policy Instruments. Paris: OECD Publishing.

Arslan-Alaton, I., Türkman, A., and Orhon, D. (2011). 'Climate Change and its Effects on Water Resources'. In A. Baba, G. Tayfur, O. Gündüz, K.W.F. Howard, M.J. Friedel, and A. Chambel (eds), Climate Change and its Effects on Water Resources Issues of National and Global Security. Dordrecht: Springer Netherlands.

Aydinalp, C., and Cresser, M.S. (2008). 'The Effects of Global Climate Change on Agriculture'. Am Eurasian J Agric Environ Sci, 3(5): 672-76.

Bosello, F., and Zhang, J. (2005). ‘Assessing Climate Change Impacts: Agriculture'. Fondazione Eni Enrico Mattei Working Paper 94.2005.

Calzadilla, A., Rehdanz, K., and Tol, R.S.J. (2011). 'Trade Liberalization and Climate Change: A Computable General Equilibrium Analysis of the Impacts on Global Agriculture'. Water, 3(2): 526-50.

Ciscar, J.C., Soria, A., Iglesias, A., Garrote, L., Moneo, M., and Quiroga, S. (2009). 'Climate Change Impacts in Europe: Final Report of the PESETA Research Project'. Joint Research Centre Scientific and Technical Reports, EUR 24093. Luxembourg: Publications Office of the European Union.

Cline, W. (2007). Global Warming and Agriculture: Impact Estimates by Country. Washington, DC: Peterson Institute for International Economics.

Cretegny, L. (2009). 'The Economics of Adaptation to Climate Change: An Integrated Assessment Framework'. Paper presented at 12th Annual Conference on Global Economic Analysis, 10-12 June, Santiago, Chile.

Dellal, İ., and Mccarl, B. (2009). 'The Economic Assessment of Climate Change on Agriculture: US and Turkish Case'. Paper presented to 1st International Congress on Global Climate Change and Agriculture, 27-29 May, Tekirdag, Turkey.

Dudu, H. (2013). 'Climate Change, Agriculture and Trade Policy: CGE Analyses at Regional, National and Global Level'. Unpublished PhD thesis, METU Department of Econoimcs, Ankara, Turkey.

Dudu, H., Çakmak, E.H., and Saraçoğlu, Ş.D. (2010). 'Climate Change and Irrigation in Turkey: A CGE approach'. İktisat Issletme ve Finans, 25(286): 9-33.

Durdu, Ö.F. (2010). 'Effects of Climate Change on Water Resources of the Büyük Menderes River Basin, Western Turkey'. Turk J Agric For, 34: 319-32.

Fankhauser, S. (2005). V aluing Climate Change: The Economics of the Greenhouse. London: Earthscan.

Fernandes, E.C., Soliman, A., Donatelli, M., Confalonieri, R., and Tubiello, F. (2012). Latin America and the Caribbean - Climate Change and Agriculture in Latin America, 2020-2050. Washington, DC: World Bank.

Flegg, A., and Webber, C. (2000). 'Regional Size, Regional Specialization and the FLQ Formula'. Regional Studies, 34(6): 563-69.

Fujihara, Y., Simonovic, S.P., Topaloğlu, F., Tanaka, K., and Watanabe, T. (2008). 'An InverseModelling Approach to Assess the Impacts of Climate Change in the Seyhan River Basin, Turkey’. Hydrological Sciences Journal, 53(6): 1121-36. 
G\&G Consulting, Başkent University Development Foundation, and TNS Siar JV (2005). Agricultural Reform Implementation Project Quantitative Household Survey Final Report. Ankara, Turkey.

General Directorate of Public Accounts (2010a). 'Cumulative Revenues and Expenditures of Provinces: Central Government Budget Expenditures (Cumulative) 2008'. Available at: http://goo.gl/6lixv (accessed 6 August 2010).

General Directorate of Public Accounts (2010b). 'Local Administrations' Budget Expenditures According to Provinces'. Available at: http://goo.gl/6lixv (accessed 6 August 2010).

Göncü, S. (2005). 'İklim Değişikliğinin Su Havzalarina Etkisinin HSPF Modeli ile İncelenmesi’. Unpublished PhD Thesis, Anadolu University, Department of Environmental Engineering, Eskisehir, Turkey.

Hertel, T.W., and Rosch, S.D. (2010). 'Climate Change, Agriculture, and Poverty'. Applied Economic Perspectives and Policy, 32(3): 355-85.

Idso, C., and Singer, F.S. (2009). Climate Change Reconsidered. Report of the Nongovernmental International Panel on Climate Change. Chicago, IL: The Heartland Institute.

Kadıŏlu, M. (2008). 'Küresel İklim Değişikliği ve Türkiye’. Mühendis ve Makina, 50(593): 15-25.

Kadıoğlu, M., and Saylan, L. (2001). 'Trends of Growing Degree-Days in Turkey'. Water, Air and Soil Pollution, 126(1): 83-96.

Kapur, B., Topaloğlu, F., and Özfidaner, M. (2007). 'Çukurova Bölgesinde Küresel Iklim Değişikliği ve Buğday Verimliliği Üzerine Etkilerine Genel Bir Yaklaşım’. Paper presented at Küresel İklim Değişimi ve Çevresel Etkileri Sempozyumu, 18-20 October, Konya, Turkey.

Kaygusuz, K. (2004). 'Climate Change Mitigation in Turkey'. Energy Sources, Part A: Recovery, Utilization, and Environmental Effects, 26(6), 563-73.

Kömüş̧̧ü, A.U.L.I.U., Erkan, A., and Öz, S. (1998). 'Possible Impacts of Climate Change on Soil Moisture Availability in the Southeast Anatolia Development Project Region (GAP): An Analysis from an Agricultural Drought Perspective'. Climatic Change, 40(3): 519-45.

Kumbaroğlu, G., Karalı, N., Arrkan, Y., and Arıkan, Y. (2008). 'CO2, GDP and RET: An Aggregate Economic Equilibrium Analysis for Turkey'. Energy Policy, 36(7): 2694-708.

Lofgren, H., Harris, R.L., and Robinson, S. (2002). 'A Standard Computable General Equilibrium (CGE ) Model in GAMS'. IFPRI Technical Guides Microcomputers in Policy Research Series 5. Washington, DC: IFPRI.

Ministry of Customs and Trade (2011). '2008 Applied Tariff Rates'. Available at: http://goo.gl/1uI2F (accessed 5 July 2011).

Nelson, G., Rosegrant, M.W., Koo, J., Robertson, R., Sulser, T., Zhu, T., ... Lee, D. (2009). 'Climate Change: Impact on Agriculture and Costs of Adaptation'. International Food Policy Research Institute Food Policy Report. Available at: www.ifpri.org/sites/default/files/publications/pr21.pdf (accessed 28 July 2014).

Önder, S., and Önder, D. (2007). 'Evaluation of Water Resources on the Basis of River Basins and the Probable Changes to Occur in Basin Management in the Future Due to Global Climate Change'. Paper presented to the International Congress on River Basin Management, 22-24 March, Ankara, Turkey.

Önol, B., Unal, Y.S.Y.S., and Dalfes, H.N.N. (2009). 'İklim Değișimi Senaryosunun Türkiye Üzerindeki Etkilerinin Modellenmesi’. İTÜ Dergisi, 8(5): 169-77. 
Özdoğan, M. (2011). 'Modeling the Impacts of Climate Change on Wheat Yields in Northwestern Turkey'. Agriculture, Ecosystems and Environment, 141(1-2): 1-12.

Palatnik, R.R., and Roson, R. (2009). 'Climate Change Assessment and Agriculture in General Equilibrium Models: Alternative Modeling Strategies'. Working Paper 67.2009. Italy: Fondazione Eni Enrico Mattei.

Parry, M.L., Canziani, O.F., Palutikof, J., Linden, P. Van Der, and Hanson, C.E. (eds) (2007). Climate Change 2007: Impacts, Adaptation and Vulnerability: Contribution of Working Group II to the Fourth Assessment Report of the Intergovernmental Panel. Cambridge, UK: Cambridge University Press.

Pauw, K., Thurlow, J., and van Seventer, D. (2010). 'Droughts and Floods in Malawi: Assessing the Economywide Effects'. Discussion Paper, 00962. Washington, DC: IFPRI.

Rosegrant, M.W., Ewing, M., Yohe, G., Burton, I., Huq, S., and Valmonte-Santos, R. (2008). Climate Change and Agriculture: Threats and Opportunities. Eschborn: Climate Protection Programme for Developing Countries.

Şensoy, S., Demircan, M., and Alan, İ. (2008). 'Trends in Turkey Climate Extreme Indices from 1971 to 2004'. Paper presented to BALWOIS 2008 Conference, 27-31 May Ohrid, Republic of Macedonia.

Silverman, B. (1992). Density Estimation for Statistics and Data Analysis. London: Chapman and Hall.

Social Assistance and Solidarity Fund (2010). 2009 Annual Report. Ankara, Turkey: Social Assistance and Solidarity Fund.

Social Security Institute (2010). '2009 Annual Statistics Book: Number of Persons in the Social Security Coverage and Rate to the Turkey Population'. Available at: www.sgk.gov.tr (accessed 5 August 2010).

Stern, N. (2006). Stern Review on the Economics of Climate Change. Cambridge, UK: Cambridge University Press.

Telli, Ç., Voyvoda, E., and Yeldan, E. (2008). 'Economics of Environmental Policy in Turkey: A General Equilibrium Investigation of the Economic Evaluation of Sectoral Emission Reduction Policies for Climate Change'. Journal of Policy Modeling, 30(2): 321-40.

Thurlow, J. (2008). A Recursive Dynamic CGE Model and Microsimulation Poverty Module for South Africa. Washington, DC: IFPRI.

Thurlow, J., Zhu, T., and Diao, X. (2012). 'Current Climate Variability and Future Climate Change: Estimated Growth and Poverty Impacts for Zambia'. Review of Development Economics, 16(3): 394-411.

Tol, R.S.J. (2010). 'The Economic Impact of Climate Change'. Perspektiven der Wirtschaftspolitik, 11: $13-37$.

Tunc, G.I., Turut Asık, S., and Akbostanci, E. (2007). ' $\mathrm{CO}_{2}$ Emissions vs. $\mathrm{CO}_{2}$ Responsibility: An Input-Output Approach for the Turkish Economy’. Energy Policy, 35(2): 855-68.

TurkStat (2010a). 'Comparative Regional Database: Agriculture'. Available at: www tuik.gov.tr (accessed 6 August 2010).

TurkStat (2010b). 'Consumption, Income and Welfare Indicators'. Available at: www.tuik.gov.tr (accessed 7 May 2010).

TurkStat (2010c). 'Comparative Regional Database: Foreign Trade'. Available at: www.tuik.gov.tr (accessed 6 August 2010). 
TurkStat (2011a). 'Environmental Statistics'. Available at: www.tuik.gov.tr (accessed 13 May 2011).

TurkStat (2011b). 'Annual Industry and Services Statistics'. Available at: www.tuik.gov.tr (accessed 13 May 2011).

TurkStat (2011c). 'Regional Household Labor Force Survey'. Available at: www.tuik.gov.tr (accessed 13 May 2011).

TurkStat (2014). 'Nomenclature of Territorial Units for Statistics - Level 1'. Available at: http://goo.gl/zUBQw4 (accessed 5 August 2014).

Yiğiteli, N.G. (2010). Sosyal Güvenlik Politikasi Değişikliklerinin Etkileri: Türkiye için Bir Sosyal Hesaplar Matrisi Çarpan Çözümlemesi [The Effects of Social Security Policies Diversifications: Social Accounting Matrix Multiply Analysis for Turkey]. Ankara, Turkey: Gazi University. 